
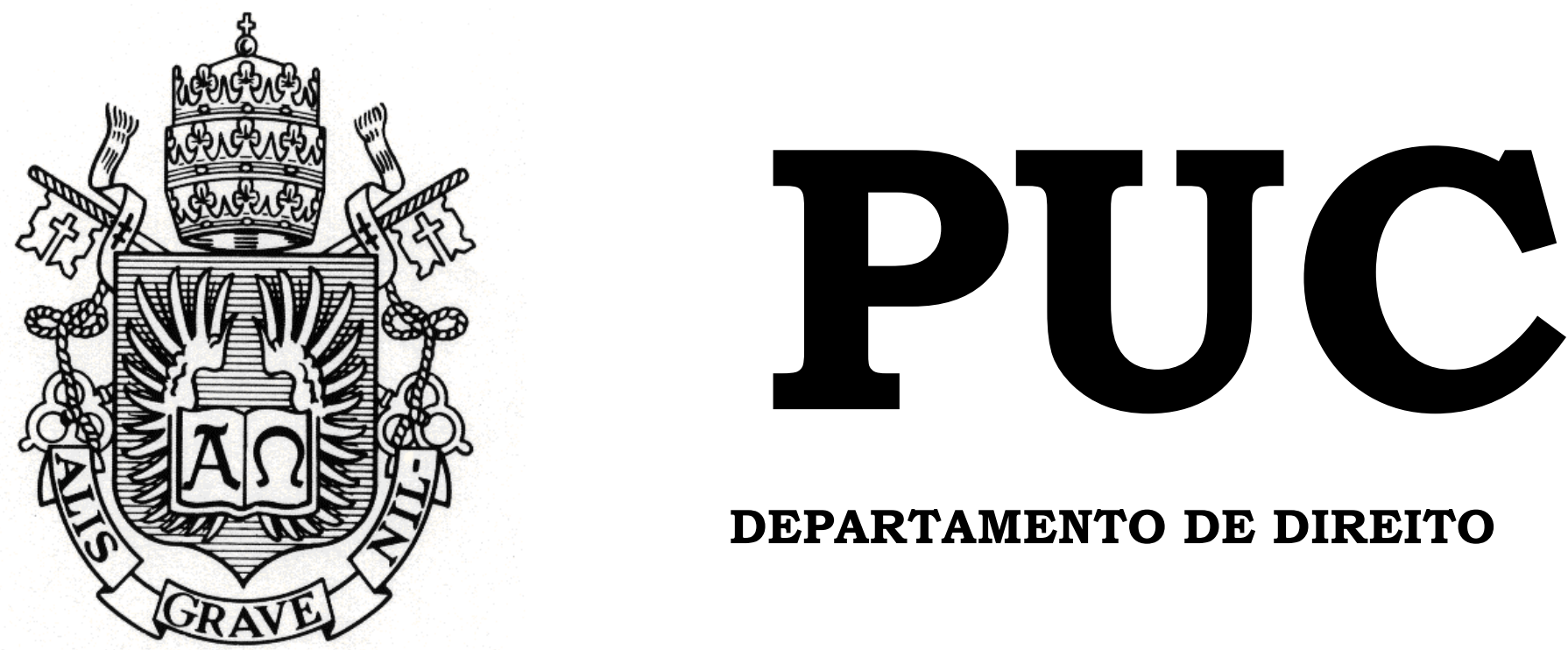

DEPARTAMENTO DE DIREITO

\title{
Maternidade no Cárcere - Um estudo reflexivo acerca da prisão feminina e o exercicio da maternidade no sistema penitenciário brasileiro
}

por

Luciana Fernandes Gregol

ORIENTADOR: Sérgio Chastinet Duarte Guimarães COORIENTADORA: Victoria de Sulocki

2016.2

PONTIFÍCIA UNIVERSIDADE CATÓLICA DO RIO DE JANEIRO

RUA MARQUÊS DE SÃO VICENTE, 225 - CEP 22453-900

RIO DE JANEIRO - BRASIL 


\title{
Maternidade no Cárcere - Um estudo reflexivo acerca da prisão feminina e o exercicio da maternidade no sistema penitenciário brasileiro
}

\author{
por \\ Luciana Fernandes Gregol
}

Monografia apresentada ao Departamento de Direito da Pontificia Universidade Católica do Rio de Janeiro (PUC-Rio) para a obtenção do Título de Bacharel em Direito.

Orientador(a): Sérgio Chastinet Duarte Guimarães

2016.2 


\section{Agradecimentos:}

Incialmente, agradeço aos meu pais, Carlos e Eliane, transmissores de todos os princípios e valores que carrego comigo. Obrigada por todo amor, educação, dedicação e incentivo ao estudo e principalmente à vida. Sem eles, este trabalho e muitos dos meus sonhos jamais se realizariam.

Ao Eduardo, responsável pelo sentimento mais sincero que guardo em mim. Obrigada pelo companheirismo incondicional, todo apoio, sintonia e amor.

Aos meus orientadores, Sergio e Victoria, por todo apoio e atenção, bem como por compartilhar comigo seus conhecimentos.

À todos os professores desta instituição, por toda aprendizagem e crescimento que me proporcionaram ao longo do curso.

E a todos que direta, ou indiretamente, contribuíram para meu desenvolvimento pessoal e acadêmico. 


\section{Resumo}

O presente trabalho debruça-se sobre a situação das mulheres que vivenciam a maternidade nas penitenciárias brasileiras. Ao descrever a precária situação do sistema penitenciário brasileiro, contextualiza a participação feminina na criminalidade e, consequentemente, na população carcerária. Identifica o perfil das mulheres presas, revelando a predominância da condenação por envolvimento com drogas e o consequente aumento da taxa de encarceramento feminino após o advento da Lei 11.343/2006. A seguir, trata das particularidades do aprisionamento feminino e, especificamente, da maternidade. Ressaltando a necessidade de um tratamento diferenciado do tema, identifica os avanços experimentados em âmbito internacional, através das Regras de Bangkok. A seguir, discorre sobre o tratamento conferido ao tema pela legislação nacional, contrastando-o com a realidade das penitenciárias brasileiras, identificando os principais obstáculos ao exercício da maternidade e revelando sua fiel rotina de violação dos direitos e garantias assegurados à estas mulheres enquanto seres humanos e mães. Analisa-se então, a atuação do Poder Judiciário como principal gargalo na garantia de seus direitos, refletindo sobre a cultura brasileira de encarceramento em massa e a adoção de medidas alternativas à pena privativa de liberdade. Por fim, reconhece a prisão domiciliar como principal solução para tal problemática e busca propostas de aplicação imediata, capazes de reduzir as mazelas aqui identificadas no cotidiano prisional.

Palavras-chave: Cárcere; Sistema Prisional; Maternidade; Mulher; Direitos Humanos; Lei de Execução Penal. 


\section{Sumário}

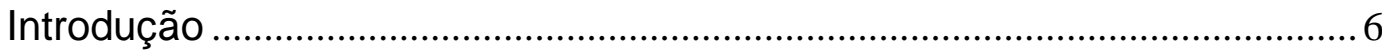

Capítulo 1 : A contextualização da mulher no sistema penitenciário brasileiro

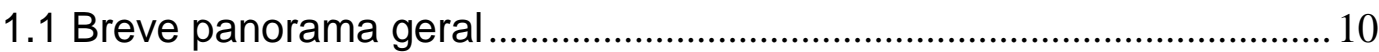

1.2 A participação feminina na população carcerária brasileira.....................11

1.3 O perfil das mulheres privadas de liberdade no Brasil ........................... 13

1.4 A lei 11.343/2006 e o aumento de mulheres encarceradas.................... 17

Capítulo 2: O aprisionamento feminino e seu tratamento sob a perspectiva

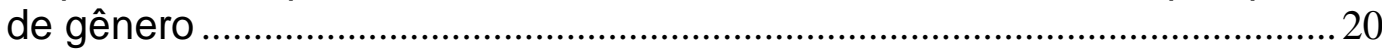

2.1 Particularidades da mulher na prisão ………………………………....... 20

2.2 O fenômeno da maternidade......................................................................22

2.3 As Regras de Bangkok e o viés garantista internacional ........................23

Capítulo 3: A Maternidade e seu exercício no cárcere brasileiro ………....26

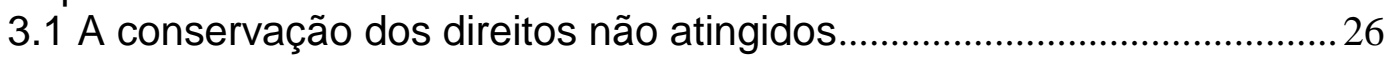

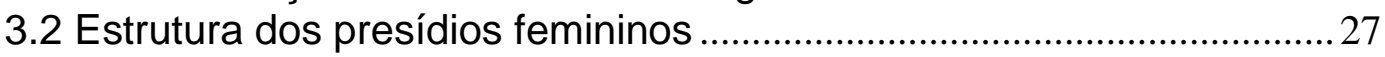

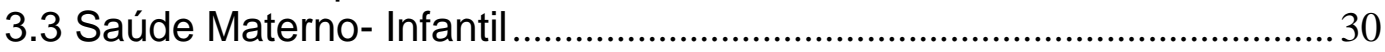

3.4 Direitos Maternos-Reprodutivos ................................................................... 35

3.5 Obstáculos na manutenção dos vínculos familiares e afetivos ............. 45

Capítulo 4: O Poder Judiciário como principal gargalo na garantia dos direitos das presas........................................................................................ 49

4.1 A cultura brasileira de encarceramento como medida de segurança e o uso abusivo da prisão provisória ..................................................................4 49

4.2 Prisão domiciliar como alternativa às penas privativas de liberdade ...51

4.3 Acesso precário à justiça ............................................................................. 56

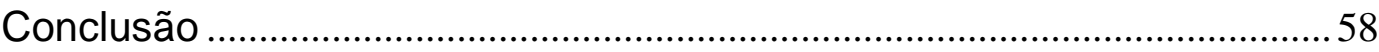

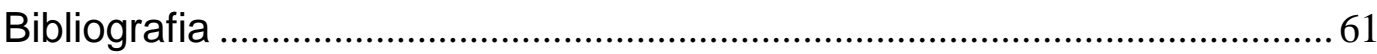




\section{Lista de abreviações:}

ECA - Estatuto da Criança e do Adolescente

LEP - Lei de Execução Penal

ONU - Organização das Nações Unidas

DEPEN - Departamento Penitenciário Nacional

INFOPEN - Levantamento Nacional de Informações Penitenciárias realizado

pelo Departamento Penitenciário Nacional

IBGE - Instituto Brasileiro de Geografia e Estatística

PNSSP - Plano de Saúde no Sistema Penitenciário 


\section{Introdução}

Os presídios brasileiros são mundialmente reconhecidos pelas múltiplas e mais intensas formas de violação dos direitos humanos. A falência do sistema penitenciário brasileiro é notória e os principais problemas existentes - como a superlotação, violência e estabelecimentos em estado degradante - são resultados da adoção de um sistema punitivo repressivo pelo Estado, que vislumbra o encarceramento em massa como a única resposta aos atos delituosos praticados pelos seus cidadãos. $O$ resultado já era previsto: a cultura de encarceramento adotada foi se solidificando ao longo do tempo e a população carcerária alcançou um ritmo de crescimento jamais experimentado. Com aproximadamente 622 mil pessoas presas, o Brasil assumiu a posição da quarta maior população privada de liberdade.

Os números continuam crescendo e o falido sistema penitenciário brasileiro não mais consegue corresponder à constante demanda, revelandose incapaz de cumprir sua principal finalidade de reeducação do condenado para ressocializá-lo, reinserí-lo e reintegrá-lo na sociedade. Por ora, o cárcere é apenas um palco de tortura.

É neste contexto que a prisão feminina vem se revelando uma das práticas punitivas mais brutais já vistas. Segundo os dados do DEPEN, somente entre os anos de 2000 e 2014, a população fermina sofreu um aumento de 567,4\%, refletindo a curva ascendente do encarceramento em massa de mulheres vivenciada nos últimos anos.

Em geral, as mulheres submetidas ao cárcere são jovens, mães, de baixa renda, responsáveis pelo sustento familiar, possuem baixa escolaridade e exerciam trabalho informal. E, diferentemente do público masculino, a prática de delitos violentos não predomina entre as acusações femininas, sendo o envolvimento com o tráfico de drogas apontado como o maior responsável pelo aprisionamento do gênero e o fato de serem responsáveis pelo sustento do lar com a principal motivação. 
Ao considerarmos os dados apontados, notória se faz a falência das mais diversas facetas do Estado brasileiro, que ignora de forma descarada a importância da implementação de novas políticas públicas e insiste em prosseguir com sua fúria punitiva e o sistemático encarceramento da pobreza, adotando normas mais rígidas e penas mais severas. Nessa realidade, o aumento do encarceramento feminino tende a produzir consequências de diversas ordens e gravidades. Além das mazelas inerentes à vida em cárcere e as mais intensas formas de violação de inúmeros direitos fundamentais experimentadas por qualquer um que ingresse em ambiente prisional, a prisão desrespeita as particularidades de sua condição feminina, em um processo continuo e intenso de deterioração da cidadania e identidade destas mulheres.

A questão das mulheres encarceradas, especialmente aquelas que experimentam a gravidez e o nascimento de seus filhos na prisão, constitui um dos aspectos mais perversos da opção por uma política criminal repressiva, com foco preferencial na pena privativa de liberdade. O contexto se dá pelo fato de que tanto as instituições, como as próprias práticas penitenciárias, não levam em consideração as especificidades inerentes ao gênero. Os presídios foram pensados por homens e para homens. Desta forma, o exercício da maternidade no ambiente carcerário se torna um desafio para estas mulheres, representando uma experiência potencialmente dramática.

\footnotetext{
"No Brasil, em sua grande maioria, as prisões femininas são escuras, encardidas e superlotadas. Dormir no chão, fazendo revezamento para ficar um pouco mais confortável, é praticamente regra. Os banheiros exalam mau cheiro, a higiene nem sempre é a mais desejável, os espaços para banho de sol são inadequados e não existe a mínima estrutura para acomodar uma criança. Por tudo isso, nos presídios, não há espaço para sonhos, ideais, muito menos para maternidade. "1
}

Apesar de os diplomas legais assegurarem a estas mulheres a reclusão em estabelecimento compatível, o direito à amamentação, à convivência familiar e comunitária, bem como à saúde, educação, trabalho e assistência jurídica, dentre outros tantos, a realidade vivida por estas mães e filhos é

\footnotetext{
${ }^{1}$ SEIXAS, Taysa Matos. Os filhos da outra: A mulher e a gravidez no cárcere. 2016. Disponível em: http://emporiododireito.com.br/tag/amamentacao/ Acesso em: 25/10/2016
} 
completamente distinta. Creches e enfermarias são, quase sempre, celas adaptadas. O ambiente insalubre contribui com a proliferação de doenças, enquanto a escassez de funcionários e a falta de profissionais da saúde, equipamentos e medicamentos tornam a assistência médica - tanto física, quanto psicológica - quase que nula. A maternidade no cárcere é acompanhada pela dor e descaso por parte do Estado, onde a maior parte destas mulheres passam por esta sem receber os devidos cuidados, acompanhamento especializado ou sequer realizar o pré-natal.

Porém, é no tocante às relações sociais e familiares que a privação de liberdade assume seu caráter mais perverso. A mulher reclusa, enquanto mãe, sofre constantemente com a angustia e medo de ter, a qualquer momento, seu filho levado. Experimenta ainda a rejeição e o abandono da família e do companheiro, sendo obrigada a conviver com o ócio por ser imediatamente afastada do trabalho, estudo ou qualquer outra atividade produtiva que ocorra dentro da instituição. $\mathrm{O}$ desrespeito ao direito à amamentação e à convivência materna impacta de forma imensurável a vida destas mães e seus filhos, transformando a maternidade em uma experiência dramática e resultando, diversas vezes, na fragilização ou ainda no absoluto rompimento dos vínculos afetivos com sua prole.

Reconhecida nocividade do cenário em que a maternidade é inserida, faz-se necessária a exploração das garantias e direitos inerentes às mulheres que vivenciam a maternidade no interior de um penitenciária, contrapondo as principais disposições existentes na estrutura legal vigente no país com a realidade experimentada por estas mães ao terem sua liberdade privada. Desta forma, além de denunciar a dramática situação a que as mulheres encarceradas são submetidas no Brasil e a forma com que a maternidade é exercida neste contexto, o presente estudo colocará em evidencia a incompatibilidade existente entre o ambiente carcerário e a geração de uma nova vida, defendendo a adoção de penas alternativas à privação da liberdade como a única forma de pôr fim às brutais violações sofridas por estas mães e seus filhos. Além disso, busca através de algumas propostas, estimular o 
Estado brasileiro a criar as condições mínimas necessárias à aplicação do ordenamento jurídico vigente para que, quando inevitável o aprisionamento, seus impactados na experiência materna sejam consideravelmente reduzidos. 


\section{Capítulo 1 : A contextualização da mulher no sistema penitenciário brasileiro}

\subsection{Breve panorama geral}

A questão penitenciaria constitui um dos desafios mais complexos para os gestores públicos e sistema de justiça brasileiros. O nosso sistema punitivo, o qual possui suas raízes no patrimonialismo, na escravidão e na exclusão social, fez nascer um padrão organizacional e estrutura de estabelecimentos penais que são o próprio retrato da violação dos mais diversos direitos das pessoas que se encontram privadas de sua liberdade.

O Levantamento Nacional de Informações Penitenciárias realizado pelo Departamento Penitenciário Nacional em 2014 trouxe números gritantes e informações chocantes. Na época, o Brasil já havia ultrapassado a marca de 622 mil pessoas privadas de liberdade em estabelecimentos penais, assumindo a posição da quarta nação com maior número de presos no mundo, permanecendo atrás apenas dos Estados Unidos, China e Rússia. ${ }^{2}$

No entanto, a informação mais preocupante diz respeito à constante e acelerada tendência de crescimento de suas taxas de encarceramento nos últimos anos. Em uma década, o Brasil viu dobrar o número de pessoas encarceradas, aumentando sua população prisional na ordem de, aproximadamente, $7 \%$ ao ano. A curva de crescimento é assustadora, ainda mais diante da constatação de que esta supera o índice de crescimento da própria população brasileira. Segundo o IBGE, entre os anos de 2002 e 2013, a população brasileira cresceu $15 \%$ enquanto a população carcerária sofreu um aumento de $140 \%$, ou seja, mais do que dobrou no mesmo período. ${ }^{3}$

\footnotetext{
${ }^{2}$ BRASIL, Ministério da Justiça, Departamento Penitenciário Nacional, Levantamento nacional de informações penitenciárias - INFOPEN - dezembro 2014 (Brasília: Ministério da Justiça, Depen, 2014). p.8 Disponível em: https://www.justica.gov.br/seus-direitos/politicapenal/infopen_dez14.pdf Acesso em: 10/10/2016

3 IBGE, Brasil População total, homens e mulheres 2000-2030. Disponível em:http://seriesestatisticas.ibge.gov.br/series.aspx?no=10\&op=0\&vcodigo $=P O P 119 \& t=t a x a-$ media-geometrica-crescimento-anual-populacao Acesso em: 10/09/2016
} 
Diante da constante crescente do número de presos, os estados ampliaram e construíram mais unidades a fim de acompanhar o ritmo de crescimento da população carcerária. O relatório do DEPEN informa que entre 200 e 2014 o número de vagas triplicou. No entanto, o continuo crescimento do número de vagas não se mostrou capaz de acompanhar a velocidade do crescimento da população prisional e o déficit no referido período mais que dobrou. Os últimos dados divulgados mostraram que uma população carcerária de, aproximadamente 622.202 presos e um total de 371.884 vagas existentes, perfazendo um déficit de 250.318 vagas. O que significa que temos, aproximadamente, 2 presos por vaga.

Diante do panorama anunciado, é importante frisar que o crescimento do número de presos não cumpriu sua promessa de contenção da violência. Pelo contrário, o cenário de rebeliões e o crescente aumento da criminalidade e violência dos presos, são resultados da situação degradante em que se encontra o sistema penitenciário brasileiro, que viola os direitos fundamentais da pessoa humana e os submete a condições precárias na vida em cárcere.

A superpopulação carcerária, insalubridade das celas, alimentação de má qualidade e em pouca quantidade, assistência jurídica precária, descaso com a saúde dos internos, violência extrema entre os detentos e a ausência de atividades de educação ou de trabalho são alguns dos problemas relacionados ao sistema penitenciário brasileiro.

\subsection{A participação feminina na população carcerária brasileira}

O crescimento da população carcerária feminina tem ocorrido de forma alarmante no Brasil e no mundo todo. Desta forma, torna-se necessário compreender o fenômeno criminal a partir da inserção de uma perspectiva de gênero. As diferenciações socialmente estabelecidas entre homens e mulheres ao longo dos anos determinam a realidade criminal e, consequentemente, todo o funcionamento do sistema de justiça criminal. 
Para alguns estudiosos, o movimento feminista de busca por igualdade de oportunidades no âmbito social repercutiu no enrijecimento do tratamento penal conferido às mulheres, contribuindo para a intensificação do processo de aprisionamento feminino. A insistente discriminação de gênero também seria outro fator responsável por uma visão mais severa assumida pela justiça criminal, levando os juízes a acreditar que a discrepância entre a conduta das mulheres infratoras e a conduta que se esperava delas era ainda maior do que no caso dos homens. O que ocorre, então, é uma espécie de "dupla punição", pela prática do crime e pelo fato de ser mulher. ${ }^{4}$

Neste sentido, discorrem Larissa Pereira e Gustavo Àvila:

\begin{abstract}
"Além do estigma normalmente atribuído àquele que delinque, a mulher desviante, em face dessa cultura patriarcal, carrega o rótulo de "criminosa", bem como o de inconsequente e irresponsável (por agir sem pensar na criação dos filhos) e também acaba perdendo, perante os demais, a sua feminilidade, por praticar condutas socialmente atribuídas ao gênero masculino. Acaba que, mesmo delinquindo em menor expressão, a mulher tem sua punição majorada pelos pré-conceitos da sociedade." 5
\end{abstract}

Como os estudos de criminologia revelam, o sistema prisional é como um espelho, que tende a refletir a realidade vivenciada pela sociedade da qual se origina. A prática de condutas delituosas por mulheres deixou de ser vista como uma "fraqueza" inerente ao seu próprio gênero, passando a ver vista como criminosa, e assim contribuindo para o incremento da população carcerária brasileira.

Ao analisarmos os números, a participação das mulheres na população prisional brasileira não é tão significativa. A quantidade de mulheres condenadas por praticarem crimes é bem menor se comparada à masculina, entretanto, o ritmo de crescimento da taxa de mulheres presas chama atenção. Entre os anos de 2000 e 2014 essa taxa cresceu 567,4\% e a população feminina passou a representar $6.4 \%$ da população prisional do país,

\footnotetext{
${ }^{4}$ ISHIY, Karla Tayumi. A desconstrução da Criminalidade Feminina. São Paulo,2014. Tese de Mestrado - Faculdade de Direito da Universidade de São Paulo. p.83

5 PEREIRA, Larissa Urruth, ÁVILA, Gustavo Noronha. Política de Drogas e Aprisionamento Feminino - $O$ Tráfico e o uso na Lei de Drogas. 2013. p.5 Disponível em: http://ebooks.pucrs.br/edipucrs/anais/cienciascriminais/IV/46.pdf Acesso em: 10 nov. 2016
} 
alcançando o total de 37.380 mulheres vivendo no cárcere. Com esses números, o Brasil assume a posição do $5^{\circ}$ país com maior população prisional feminina, perdendo apenas para os Estados Unidos, China, Rússia e Tailândia. ${ }^{6}$

E, se o atual sistema prisional brasileiro vem se mostrando totalmente despreparado para alcançar suas reais finalidades com sua população masculina, quando se trata de sua real efetividade em relação à prisão feminina, principalmente ao considerarmos a fragilidade legislativa sobre o tema, a falta - ou inexistência - de instituições capacitadas, o descompasso existente entres estas e o poder judiciário, bem como a escassez de profissionais qualificados, este demonstra-se completamente falido.

O cárcere brasileiro, por si só, já é um lugar de exclusão social e desrespeitos aos mais diversos direitos do homem. No entanto, especificamente nas unidades femininas, encontramos maiores violações no tangente ao exercício de direitos de forma geral, e em especial dos direitos sexuais e reprodutivos, bem como o acesso à saúde. É evidente que o enfrentamento destas novas problemáticas requer um olhar diferenciado à compreensão da condição das mulheres encarceradas. Até o momento, contudo, existem poucos trabalhos, dados e políticas públicas relacionados ao tema, o que reforça a invisibilidade carcerária do gênero e nos leva a lidar com um conhecimento meramente superficial da real situação que as mulheres enfrentam em nossos presídios.

\subsection{O perfil das mulheres privadas de liberdade no Brasil}

Apesar da carência de informação, estudos demonstram que as mulheres alvo de nosso sistema repressor penal obedecem a um perfil prédelineado. Os dados apresentados pelo INFOPEN reforçam como o perfil é

\footnotetext{
${ }^{6}$ BRASIL, Ministério da Justiça, Departamento Penitenciário Nacional, Levantamento nacional de informações penitenciárias - INFOPEN Mulheres - junho 2014 (Brasília: Ministério da Justiça, Depen, 2014). p.8. Disponível em: https://www.justica.gov.br/noticias/estudo-traca-perfil-dapopulacao-penitenciaria-feminina-no-brasil/relatorio-infopen-mulheres.pdf Acesso em: 10/10/2016
} 
discrepante, onde a maioria destas mulheres é de jovens entre 18 e 29 anos $(50 \%)$, negras $(67 \%)$, solteiras $(57 \%)$ e com baixa escolaridade $(50 \%$ sequer possui o Ensino Fundamental Completo).

A pesquisa realizada pelo Grupo de Pesquisa em Política de Drogas e Direito Humanos do Laboratório de Direitos Humanos da Universidade Federal do Rio de Janeiro (FND/UFRJ), entrevistou 41 mulheres em situação de prisão, e constatou que metade delas estava trabalhando na época em que foi presa, em empregos irregulares (85\% sem carteira assinada), e que a maioria era responsável pelo sustento do lar. ${ }^{7}$

Até então, os dados trazidos não divergem muito do perfil dos presos do sexo masculino, reforçando apenas a grande parcela de responsabilidade que a enorme desigualdade social existente no país possui sobre as práticas de crimes. Porém, um dado discrepante é trazido pelo estudo da distribuição por gênero dos crimes tentados/consumados entre os registros das pessoas privadas de liberdade. Em relação à população total, a prática de roubo e o tráfico de drogas correspondem aos crimes de mais incidência, respondendo por $27 \%$ e $26 \%$, respectivamente, do total de crimes informados. Quando analisamos essa distribuição com recorte de gênero, no entanto, são reveladas importantes especificidades, vez que para as mulheres o crime de tráfico de drogas corresponde à $68 \%$.

A prática do crime nem sempre foi recorrente entre as mulheres, sendo a prática somente inserida no perfil das mulheres nas últimas décadas. Anteriormente, a maioria dos delitos praticados por mulheres faziam referência aos crimes passionais. Posteriormente, o perfil da mulher sofreu algumas mudanças na medida em que esta passou a se manifestar com maior liberdade dentro da vida em sociedade. E, assim, até a década de 70, conforme discorre Elizabeth Novaes, as práticas delitivas se apresentavam em duas formas:

\footnotetext{
${ }^{7}$ BOITEUX, Luciana, FERNANDES, Maíra, PANCIERI, Aline e CHERNICHARO, Luciana. Mulheres e crianças encarceradas: um estudo jurídico-social sobre a experiência da maternidade no sistema prisional do Rio de Janeiro. p.3 Disponível em: http://pbpd.org.br/wordpress/wpcontent/uploads/2015/11/M--es-encarceradas-UFRJ.pdf Acesso em 15/10/2016
} 


\begin{abstract}
"Evidenciavam-se especialmente dois tipos de manifestações: o das questões políticas, para o qual o aprisionamento se dava em repúdio a ideologias e militâncias não aceitas pelo poder maior do Estado, e o do aprisionamento de mulheres por práticas delituosas, sendo o crime de furto, a tipificação com maior incidência, garantindo mandatos de prisões e condenações pela pratica. $O$ furto era o mais praticado, era o que responsabilizava e encarcerava o sexo feminino. Mesmo em um número pequeno, e sem praticas violentas, o ato de tomar para si, o que não é seu, era "recordista" na condução de mulheres infratoras para as prisões."»
\end{abstract}

Depois dos anos de 1970, o tráfico de drogas passou a ser responsável pelo aumento de mulheres presas e surpreende ao continuar sendo o crime que superlota prisões. $\mathrm{O}$ aumento deste índice decorre da facilidade que as mulheres encontram na pratica de tal crime, vez que não são o principal foco da ação policial, se tornando assim, uma espécie de alvo dos traficantes, que muitas vezes aliciam adolescentes e mulheres para facilitar a venda da droga.

Neste contexto, expõe Ribeiro ${ }^{9}$ que: "uma explicação possível para esse fenômeno é a facilidade que a mulher possui para circular com a droga pela sociedade, por não se constituir em foco principal da ação policial". Partindo desse pressuposto Mizon et $\mathrm{al}^{10}$, expõem que: “as mulheres são vistas como alvos fáceis pelos traficantes, pois a sociedade em geral tende a não desconfiar das mesmas, portanto, teriam mais facilidade no tráfico".

A mulher na sociedade brasileira, bem como de uma forma global, aos poucos foi conquistando seu espaço e independência, assumindo assim, muitas vezes, as obrigações de sustento de seu lar. Estas obtiveram seu papel social, conquistando direitos políticos e adquirindo acesso à educação, passando a alcançar um espaço no mercado de trabalho. A construção deste padrão inovador de atividade possibilitou a transição da mulher do status

\footnotetext{
${ }^{8}$ NOVAES, Elizabete David. Uma Reflexão Teórico-Sociológica acerca da inserção da Mulher na Criminalidade. Revista Sociologia Jurídica. $\mathrm{n}^{\circ}$ 10. Jan/jun 2010. Disponível em: http://www.sociologiajuridica.net.br/ Acesso em: 20/10/2016.

${ }^{9}$ RIBEIRO, Ludmila Mendonça Lopes. Análise da política penitenciária feminina do Estado de Minas Gerais: o caso da Penitenciária Industrial Estevão Pinto. 2003. Dissertação de Mestrado. Belo Horizonte: Fundação João Pinheiro, 2003, p.64. Disponível em: http://bdtd.ibict.br/vufind/Record/FJP_5ef6b8e30765344b1c00c4c471fd8676. Acesso em: $10 / 10 / 2016$

${ }^{10}$ MINZON, Camila Valéria; DANNER, Glaucia Karina; BARRETO, Danielle Jardim. Sistema prisional: conhecendo as vivências da mulher inserida neste contexto. Akrópolis Umuarama, v.18, n.1, p. 71-81, 2010. Disponível em: http://revistas.unipar.br/akropolis/article/viewFile/3118/2212. Acesso em: 05/11/2016
} 
antes definido de esposa e de mãe, passando a receber denominação de trabalhadora. ${ }^{11}$

No entanto, a baixa escolaridade e a influência do ambiente em que estas mulheres de baixa renda encontram-se inseridas, acabam se tornando fatores responsáveis por seu envolvimento no tráfico de drogas, fazendo com quem este passe a representar sua única chance de prover o sustento de seu lar.

Outro fator que contribui para que estas passem a se envolver com o tráfico de entorpecentes é as relações afetivas existentes entre as mulheres e os homens traficantes. O tema despertou o interesse de estudiosos, fazendo com que estes buscassem explicações sobre o envolvimento das mulheres com esta modalidade criminosa. Para alguns, esse envolvimento se desencadeia a partir da ligação afetiva da mulher com um traficante e que, por uma razão específica, ficou impedido de fazê-lo e permitiu que a mulher ocupasse esta função para complementação da renda familiar. Para outros, a mulher estaria entrando em modalidades de economia informal, que também pode ser baseada em atividades ilegais, como uma forma de contribuir para a economia doméstica, como é o caso do tráfico de drogas. ${ }^{12}$

A pesquisa realizada pelo FND/UFRJ confirma tais teses, na medida em que constata que, entre as mulheres entrevistadas, a maioria era ré primária $(70 \%)$ e tinha algum parente preso $(75,6 \%)$, sendo que quase metade delas tinha o seu companheiro preso $(46,3 \%)$, dos quais $52,6 \%$ pelo crime de tráfico. Assim, ao presenciarem a prisão de homens com os quais possuíam laços afetivos, essas mulheres, com baixa escolaridade e já excluídas do mercado de trabalho, passaram a ver o tráfico de drogas como uma

\footnotetext{
${ }^{11}$ LOBATO, Aline et al. Mulheres criminosas: analisando a relação entre a desestruturação familiar $e$ criminalidade. p. $10 . \quad$ Disponível em: http://abrapso.org.br/siteprincipal/images/Anais_XVENABRAPSO/242.\%20mulheres\%20crimino sas.pdf Acesso em: 20/10/2016

${ }^{12}$ CARVALHO, Denise; JESUS, Maria Gorete Marques de. Mulheres e oTráfico de Drogas: Um Retrato das Ocorrências de Flagrante na Cidade de São Paulo. Revista do Laboratório de Estudos da Violência da UNESP/Marília. 2012. Ed. 9 - Maio/2012. p.179 Disponível em: http://www2.marilia.unesp.br/revistas/index.php/levs/article/view/2285/1882 Acesso em: $05 / 10 / 2016$
} 
necessidade para manter o sustento da família, honrar com os compromissos pendentes relacionados ao então preso, ou até mesmo para manter o vício do homem no presídio.

Neste contexto, a conduta delituosa das mulheres foi desvinculada da categoria de gênero - responsável pelas práticas de crimes "femininos", como o infanticídio, aborto e homicídio passional - passando a se inserir, de forma generalizada, na chamada "criminalidade de pobreza". ${ }^{13}$ Sendo assim, a elevação no número de mulheres presas, além de retratar o crescimento da criminalidade de ambos os sexos, representa também uma mudança no imaginário social e a minimização da clemencia da justiça em relação à estas mulheres transgressoras, as quais eram vistas com maior tolerância há alguns anos atrás.

\subsection{A lei 11.343/2006 e o aumento de mulheres encarceradas}

Promulgada em agosto de 2006, a Lei 11.343, chamada Nova Lei de Drogas e Entorpecentes, alterou os dispositivos da Lei 6.368 de 1976 visando resolver uma antiga problemática brasileira: O Tráfico de Drogas.

Além de tornar mais severas as penas aos incursos em tráfico de drogas, a nova lei passou a penalizar o uso de entorpecentes com sanções diversas da pena privativa de liberdade. Fator este que, à primeira vista, poderia contribuir para a diminuição ou estabilização do número de presos por drogas, sobretudo num país onde a regra é o cárcere e os presídios encontram-se absurdamente superlotados. Contudo, os estudos realizados pelo Instituto de Pesquisa e de Cultura Luiz Flávio Gomes (IPC-LFG), baseados nos números divulgados pelo DEPEN (Departamento Penitenciário Nacional), apontaram exatamente o contrário.

Em dezembro de 2006 o número total de presos no Brasil era de 401.236 detentos, sendo 11,2\% presos por drogas. Em dezembro de 2010,

\footnotetext{
${ }^{13}$ ESPINOZA, Olga. A mulher encarcerada e face do poder punitivo. São Paulo: IBCCrim, 2004. p.126
} 
o total de presos era de 496.251 detentos, sendo $20 \%$ por envolvimento com drogas. Ou seja, o percentual de presos por entorpecentes praticamente dobrou no período mencionado. Em apenas quatro anos, houve um crescimento de $123 \%$ no número de presos por drogas, superando o crescimento do número total de presos do mesmo período, que foi de apenas $24 \% .^{14}$

Quando direcionamos o foco para as mulheres, considerando o panorama anunciado e ressaltados os diversos fatores capazes de contribuir para o envolvimento destas no tráfico de drogas, é possível estabelecer uma relação direta entre o exuberante aumento da população carcerária feminina e o advento da nova lei.

Esse aumento de mulheres presas por causa do tráfico teria por causa a maioria das mulheres desempenhar funções subalternas na escala hierárquica. Em geral, seu papel no tráfico é o de transporte, vigilância e manutenção dos entorpecentes em suas casas - atividades que permitem conciliação com as responsabilidades de cuidado e domésticas; contudo, são também as atividades mais visíveis do tráfico, o que as deixam mais vulneráveis em relação ao controle penal. ${ }^{15}$

Em geral, os protagonistas continuam sendo os homens, e as mulheres atuam apenas como coadjuvante. Dificilmente alguma delas possuem papel de maior importância no tráfico, mantendo sua histórica posição subalterna e envolvendo-se basicamente nas funções conhecidas como vapor ( que é o encarregado pelo preparo e embalagem do produto); "mula” ( que são os

\footnotetext{
14 BRASIL, Ministério da Justiça, Departamento Penitenciário Nacional, Levantamento nacional de informações penitenciárias - INFOPEN - dezembro 2014 (Brasília: Ministério da Justiça, Depen, 2014). Disponível em: https://www.justica.gov.br/seus-direitos/politica-penal/infopen_dez14.pdf Acesso em: 08/08/2016

15 BRASIL, Ministério da Justiça. Secretaria de Assuntos Legislativos. Dar à luz na sombra: condições atuais e possibilidades futuras para o exercício da maternidade por mulheres em situação de prisão. Brasília: Ministério da Justiça, IPEA,2015.Série Pensando o Direito, n.51. p.76. Disponível em: http://www.justica.gov.br/noticias/201clugar-de-crianca-nao-e-na-prisao-nemlonge-de-sua-mae201d-diz-pesquisa/pesquisa-dar-a-luz-na-sombra-1.pdf. Acesso em: 10/11/2016.
} 
indivíduos responsáveis pelo transporte da droga); e "olheiro" ( pessoas que se posicionam em locais estratégicos para vigiar as vias de acesso) $)^{16}$

A magistrada Telma de Verçosa Roessing, durante o II Encontro Nacional do Encarceramento Feminino promovido pelo Conselho Nacional de Justiça e o Departamento Penitenciário Nacional, defendeu a tese de que a atual Lei de Drogas é acometida de uma generalidade que prejudica as mulheres mais pobres. Segundo a juíza, a problemática da lei, está em não levar em consideração a posição da acusada no esquema de tráfico de drogas, vedando que o juiz faça distinção entre os pequenos e grandes traficantes. $\mathrm{Na}$ prática, isso resulta na atribuição de punições equânimes entre sujeitos com menor participação no crime e os criminosos que assumem cargos de maior importância. Desta forma, casos como o de mulheres que tentam entrar nos estabelecimentos prisionais portando entorpecentes para os seus companheiros e respondem com pena semelhantes a aquelas direcionadas aos chefes de "bocas de fumo" tornam-se recorrentes. ${ }^{17}$

Desta forma, a realidade evidencia que novas leis, ainda que bemintencionadas, se desacompanhadas de sérias políticas e medidas criminais e sociais, não são suficientes para amenizar problemas sociais ou a superlotação carcerária. A penalização excessiva acaba acarretando efeitos distintos dos desejados pelo poder estatal, vez que por diversas vezes o remédio penal é utilizado como uma forma de resposta direta aos problemas sociais e conflitos que surgem na sociedade, sem sequer verificar sua eficácia instrumental como meio de prevenção ao delito. Nestes casos, os resultados são muito piores e sua aplicação, muitas vezes equivocada, pode contribuir diretamente para a deterioração e saturamento do sistema penitenciário.

\footnotetext{
16 BASTOS, Paulo Roberto da Silva. Criminalidade feminina: Estudo do perfil da população carcerária feminina da Penitenciária Professor Ariosvaldo de Campos Pires - Juiz de Fora $(M G) / 2009$. Disponível em: http://www.ambitojuridico.com.br/site/index.php?n_link=revista_artigos_leitura\&artigo_id=8444 Acesso em: $05 / 11 / 2016$

${ }^{17}$ CNJ. Lei sobre drogas deve mudar para evitar penas desproporcionais à mulher, defende juíza. 2013. Disponível em: http://www.cnj.jus.br/noticias/cnj/60511-lei-sobre-drogas-deve-mudar-paraevitar-penas-desproporcionais-a-mulher-defende-juiza Acesso em: 20/10/2016.
} 


\section{Capítulo 2: 0 aprisionamento feminino e seu tratamento sob a perspectiva de gênero}

\subsection{Particularidades da mulher na prisão}

A inserção da mulher na realidade prisional trouxe grandes impactos, representando um dos maiores problemas do sistema prisional brasileiro, o qual só pode ser compreendido através de uma análise das especificidades inerentes ao gênero. As diferenças sociais existentes entre homens e mulheres fazem com que estas, quando encarceradas, convivam com a vulnerabilidade própria do gênero feminino, somada à condição inferiorizada que recai sobre os presos em geral.

Ao ingressar em um presídio para cumprir sua pena, a mulher passa por momentos de conflitos internos, em função da realidade em que passa a ser inserida. A privação de liberdade afeta o autocuidado e, consequentemente, seu corpo, sua sexualidade, saúde e autoestima. “ Tratar da mulher no sistema penitenciário representa um dilema, pois a esta sempre coube o cuidado com os afazeres domésticos, com a família e filho. Trata-se de uma imagem de fragilidade, fraqueza e leveza, já associada ao gênero no imaginário social. ${ }^{18}$ Sobre o tema, Marcos Fuchs, diretor adjunto da organização não governamental internacional Conectas afirma que "na prática, isso significa que o cárcere agrava a situação de desigualdade de gênero de nossa sociedade." 19

No caso do encarceramento feminino, há uma histórica omissão dos poderes públicos, manifesta na completa ausência de políticas públicas que considerem a mulher encarcerada como sujeito de direitos e, muito

\footnotetext{
${ }^{18}$ LIMA, Marcia. Da visita íntima à intimidade da visita: a mulher no sistema prisional. Tese de Mestrado. Universidade de São Paulo. São Paulo, 2006. p. 11. Disponível em: http://www.teses.usp.br/teses/disponíveis/6/6136/tde-24032008-085201/pt-br.php Acesso em: 11 nov. 2016

19 CONECTAS. Mulheres e Encarceradas: Dupla Punição. Disponível em: http://www.conectas.org/pt/acoes/justica/noticia/28793-mulheres-e-encarceradas-dupla-punicao. Acesso em: 16/10/2016
} 
particularmente, às suas especificidades advindas do seu próprio gênero. Isso porque, como se verá no curso deste trabalho, há toda uma ordem de direitos das mulheres presas que são violados de modo acentuado pelo Estado brasileiro, que vão desde a desatenção a direitos essenciais como à saúde, até aqueles implicados numa política de reintegração social, como a educação, o trabalho e a preservação de vínculos e relações familiares. ${ }^{20}$

A complexidade que caracteriza o sistema penitenciário brasileiro não exclui o encarceramento feminino, onde os severos problemas existentes no sistema carcerário do país, tais como a falta de higiene, a precariedade dos serviços de saúde e jurídicos, entre outros, bem como, a complexidade administrativa do setor, aliados à superlotação do sistema encontram-se presentes na realidade destas mulheres.

A situação prisional brasileira é uma verdadeira calamidade, mas a realidade das mulheres em situação de cárcere é ainda mais severa, pois as políticas públicas para os presídios, que já são limitadas, não consideram as especificidades femininas. Historicamente, a ótica masculina tem sido tomada como regra para o contexto prisional, com prevalência de serviços e políticas penais direcionados para homens, deixando em segundo plano as diversidades que compreendem a realidade prisional feminina, que se relacionam com sua raça, etnia, idade, deficiência, orientação sexual, nacionalidade, situação de gestação e maternidade, entre tantas outras nuanças. É possível que a circunstância se dê pelo fato de que as políticas penitenciarias estejam voltadas para atender a alta taxa de aprisionamento masculino. No entanto, a presença reduzida do gênero não ser utilizada como justificativa para o abandono e consequente violação de seus direitos.

Neste sentido, a promotora de justiça do Estado de Minas, Vanessa Nogueira Simone, afirma que "as mulheres são desconsideradas dentro da

${ }^{20}$ CEJIL, Centro pela Justiça e pela Justiça Internacional et al. Relatório sobre as mulheres encarceradas no Brasil. Rio de Janeiro,2007. p.46. Disponível em: http://carceraria.org.br/wpcontent/uploads/2013/02/Relato\%CC\%81rio-para-OEA-sobre-Mulheres-Encarceradas-no-Brasil2007.pdf Acesso em: 05/11/2016. 
instituição penitenciária, já que o sistema, como outras esferas, se rege, fundamentalmente, por um modelo 'masculino' em que a norma se dita e se formula a partir das necessidades dos homens". ${ }^{21}$ Entretanto, a não aplicação da individualização da pena acaba impedindo que a prática punitiva exercida pelo Estado atinja suas finalidades político-criminais, o que só se torna possível ao reconhecer que cada fato ou delinquente possui particularidades que dependem de um tratamento diferenciado. ${ }^{22}$

Não são necessários esforços para reconhecer a condição específica de vulnerabilidade a que estão submetidas as mulheres privadas de liberdade e a necessária atenção especial que os Estados devem dar a essa situação, o que infelizmente, não está sendo observado em âmbito brasileiro.

\subsection{O fenômeno da maternidade}

Reconhecida a atual conjuntura do sistema penitenciário brasileiro e a vulnerabilidade feminina neste ambiente, além das mazelas estruturais comuns ao próprio sistema carcerário e as violações contra os mais diversos direitos das mulheres encarceradas, o aprisionamento feminino traz consigo uma especificidade de extrema importância: a maternidade.

A identificação do perfil da população carcerária feminina, principalmente ao considerar o fato que a maior parte se encontra em faixa etária propícia a reprodução humana, facilita a compreensão das razoes pelas quais o fenômeno da maternidade encontra-se regularmente inserido no cenário de cárcere brasileiro. Atualmente, $80 \%$ da população carcerária feminina brasileira é composta por mães e, embora grande parte destas detentas já fossem mães antes de serem presas, muitas delas tornaram-se mãe enquanto reclusas. Em todo o Brasil existem, aproximadamente, 263 crianças

\footnotetext{
${ }^{21}$ SIMONE, Vanessa Fusco Nogueira. Filhos do cárcere: limites e possibilidades de garantir os direitos fundamentais dos filhos das mulheres privadas de liberdade no Brasil. Porto Alegre: Núria Fabris, 2013, p. 33.

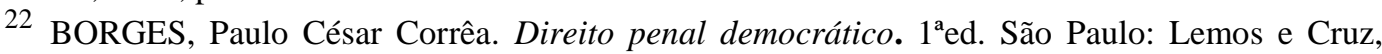
2005.p. 87
} 
em penitenciárias masculinas ou mistas, e 83 crianças em penitenciárias femininas. ${ }^{23}$

Desta forma, o Estado brasileiro e seu sistema de justiça criminal devem considerar todas as particularidades femininas durante o julgamento e execução da pena destas mulheres, a fim de preservar todos os seus direitos enquanto cidadãs brasileiras e os novos direitos que surgem com a vida que estas carregam em seu ventre.

\subsection{As Regras de Bangkok e o viés garantista internacional}

O crescente incremento da população feminina encarcerada vivido nos últimos anos e a verificação das mais brutais formas de violação dos seus direitos em determinados países repercutiu mundial, fazendo com que o assunto se tornasse o principal tema da $65^{\mathrm{a}}$ Assembleia da Organização das Nações Unidas (ONU). Realizada no ano de 2010, teve como resultado a criação normas internacionais para o tratamento de mulheres encarceradas, as chamadas Regras de Bangkok. Estas visam complementar as Regras Mínimas para o Tratamento do Preso e as Regras Mínimas para a Elaboração de Medidas não Privativas de Liberdade (Regras de Tóquio), as quais, não consideraram a realidade da mulher encarcerada, muito menos qualquer necessidade específica de sua realidade.

O documento tornou-se o principal marco normativo internacional a abordar essa problemática, propondo um olhar diferenciado para as especificidades de gênero no encarceramento feminino, tanto no campo da execução penal, como também na priorização de medidas não privativas de liberdade, ou seja, que evitem a entrada de mulheres no sistema carcerário. ${ }^{24}$ Neste, a maternidade e seu exercício no ambiente prisional foram reconhecidos como uma dos mais sérios dramas vividos pelas mulheres que

\footnotetext{
${ }^{23}$ CONECTAS, op. cit., 2015.

24 ONU. Regras de Bangkok. Adotada pela Assembleia Geral em 16/03/11. Resolução A/RES/65/229. p.10 Disponível em: http://www.cnj.jus.br/files/conteudo/arquivo/2016/03/27fa43cd9998bf5b43aa2cb3e0f53c44.pdf Acesso em: 03/10/ 2016
} 
têm sua liberdade privada, ocasionando severos danos à mãe e seu bebe. Assim, as regras buscaram garantir que a experiência materna, quando inevitável que ocorra fora das grades, se dê da forma mais saudável possível, preservando todos os direitos das mulheres enquanto mães e seus filhos.

Para tanto, os cuidados devem surgir desde o momento de ingresso, quando a mulher possa definir com quem deixar os filhos enquanto estiver presa e ainda, caso necessário, ter sua prisão suspensa enquanto procura resolver esta questão. Além disso, as regras buscam assegurar que, no momento de inclusão, constem em seu prontuário informação acerca de seus filhos, quantos são, sob os cuidados de quem estão ou se necessitam de abrigo.

A importância da amamentação e da convivência entre mães e seus filhos também ganha destaque, garantindo de forma expressa o aleitamento materno e estabelecendo que não se impedirá a mulher de amamentar seu filho, a menos que haja justificativas concretas de saúde para isso. O documento segue dispondo que as mulheres em fase de amamentação devem receber especial acompanhamento médico e alimentar. Apesar de não especificarem o prazo de amamentação, enfatizam que a decisão do momento de separação da mãe de seu filho deve ser feita caso a caso e fundada no melhor interesse da criança, efetivando-se apenas quando alternativas de cuidado da criança tenham sido identificadas.Outro aspecto abordado pelas normas é a assistência medica e cuidados com a saúde mental das mulheres, tomando por conta a importância de um efetivo controle de saúde dentro das unidades.

Apesar de propor um tratamento diferenciado para as mulheres no ambiente carcerário, a fim de reduzir o inferno vivido por estas, a pena privativa de liberdade é vista como uma medida inadequada para mulheres enquanto mães e seus filhos, devendo ser aplicada somente em casos extremos. Neste sentido, o documento determina que os Estados optem por formas alternativas de lidar com mulheres infratoras, empregando, sempre 
que possível, medidas despenalizadoras e alternativas à prisão, inclusive à prisão cautelar.

O documento é fruto de anos de estudos e deve servir como "uma diretriz legítima para as políticas públicas a serem adotadas pelos países que a ratificaram" 25 , entre os quais o Brasil faz parte. E, apesar dos princípios trazidos por estas terem inspirado algumas mudanças na legislação nacional, a aplicação das referidas regras não é verificada por parte do Estado brasileiro, o qual vem se revelando incapaz de respeitar sequer sua própria normativa interna.

Como aponta Heidi Ann Cerneka, em sua obra Presos que Menstruam, as regras não têm caráter obrigatório para o Brasil, mas "têm por objetivo estabelecer princípios e regras de uma boa organização penitenciária e das práticas relativas ao tratamento de prisioneiros. $\mathrm{O}$ Estado brasileiro, por ser membro da ONU, tem o dever de respeitar as regras, mas não pode sofrer sanção por não cumpri-las". ${ }^{26}$

Apesar do insistente descumprimento por parte do Estado brasileiro, as Regras de Bangkok representam a única esperança de melhoria do cenário no qual a população carcerária feminina está inserida. A relevância dos direitos e princípios contidos no documento da ONU, bem como a necessidade de imediata aplicação das normas criadas, já foram reconhecidas mundialmente e devem ser encaradas como um compromisso pelas autoridades brasileiras, atribuindo caráter obrigatório à sua aplicação e contribuindo para a redução do recorrente desrespeito aos direitos e especificidades do gênero no âmbito carcerário.

\footnotetext{
${ }^{25}$ BRASIL. Núcleo Especializado da Infância e Juventude - Defensoria Pública de São Paulo. Mães no cárcere: Observações técnicas para a atuação profissional em espaços de convivência de mulheres e seus filhos. São Paulo, 2011. p. 2 Disponível em: http://www.saude.sp.gov.br/resources/ses/perfil/profissional-da-saude/grupo-tecnico-de-acoesestrategicas-gtae/saude-das-populacoes-privadas-de-liberdade/saude-do-sistemapenitenciario/cartilha-maes-no-carcere/cartilha_maes_no_carcere.pdf Acesso em: 10/10/2016 ${ }^{26}$ CERNEKA, Heidi Ann. Homens que menstruam: Considerações acerca do sistema prisional às especificidades da mulher. 2009. p. 66 Disponível em: http://www.domhelder.edu.br/revista/index.php/veredas/article/view/6. Acesso em: 25/10/2016
} 


\section{Capítulo 3: A Maternidade e seu exercício no cárcere brasileiro}

\subsection{A conservação dos direitos não atingidos}

Em um Estado Democrático de Direito, é correto afirmar que o exercício do poder punitivo do Estado está intimamente ligado ao respeito aos direitos e garantias individuais de seus cidadãos, os quais encontram-se previstos, especialmente, na Constituição Federal de 1988, no Código Penal e na Lei de Execução Penal.

Neste sentido, Nucci ensina que a execução penal é "fase do processo penal, em que se faz valer o comando contido na sentença condenatória penal, impondo-se, efetivamente, a pena privativa de liberdade, a restritiva de direitos ou a pecuniária. "Ao tratar do assunto, o autor reflete sobre a importância da individualização da pena, que deve estar presente em todas as fases do processo penal, inclusive na execução da pena. Segundo ele, inicialmente, o legislador é o primeiro responsável por esta individualização, pois é quem cria um novo tipo de pena e a determina quanto à sua espécie, restringindo a atuação do magistrado. Em seguida, o julgador deve fixar a pena em concreto, o regime, bem com os benefícios cabíveis, considerando as particularidades do caso. Por fim, a última etapa ocorre durante a execução penal, momento no qual nos deparamos com a mutabilidade do título executivo judicial penal. ${ }^{27}$

A partir disso, faz-se necessária análise acerca da conservação dos direitos não atingidos pela sentença penal imposta. O tema tem previsão legal na Constituição Federal ${ }^{28}$ e no Código Penal, o qual dispõe que o preso conserva todos os direitos não atingidos pela perda da liberdade, impondo-se a todas as autoridades o respeito à sua integridade física e moral. ${ }^{29}$

\footnotetext{
${ }^{27}$ NUCCI, Guilherme de Souza. Manual de processo penal e execução penal: 4 ed. - São Paulo: Editora Revista dos Tribunais,2008. p.1002

${ }^{28}$ BRASIL. Constituição da República Federativa do Brasil de 1988. Art. 5º XLIX.

${ }^{29}$ BRASIL. Decreto-Lei 2.848, de 07 de dezembro de 1940. Código Penal. Diário Oficial da União, Rio de Janeiro, 31 dez. 1940. Art. 38.
} 
É evidente que a perda da liberdade acarreta, consequentemente, à limitação de outros direitos ligados a este, como exemplifica Nucci ao explicar que aquele que tem pela pena a sua liberdade cerceada, acaba por não ter prerrogativa integral à intimidade. Contudo, o mesmo não pode se estender e atingir os demais direitos inerentes àquele indivíduo, como por exemplo, o direito à honra, à integridade física, entre outros.

Considerando o cenário descrito e trabalhando com a perspectiva de que toda maternidade em situação prisional é vulnerável, a preservação de determinados direitos inerentes a esta torna-se um pressuposto para que seu exercício dentro das grades ocorra da forma menos prejudicial possível tanto para a mãe, quanto para seu filho.

No entanto, o Estado mostra-se falho e incapaz de cumprir com suas obrigações de manutenção dos demais direitos de sua população carcerária, principalmente quando os sujeitos são mulheres pleno exercício da maternidade. A afronta aos mais diversos direitos garantidos pela legislação brasileira transformam a benção da maternidade em um dos maiores dramas já vivido por estas mulheres, capaz de causar sequelas irreparáveis a estas e seus filhos.

\subsection{Estrutura dos presídios femininos}

Ao tratar da prisão feminina, a Lei de Execução Penal prevê que o cumprimento da pena deverá ocorrer em estabelecimento próprio e adequado à sua condição pessoal, o qual deverá conter, exclusivamente, agentes do mesmo sexo na segurança de suas dependências internas. A destinação dos estabelecimentos segundo o gênero, portanto, é um dever estatal, e representa aspecto fundamental para a implementação de políticas públicas específicas, voltadas a esse segmento.

Entretanto, em detrimento do que dispõe seu ordenamento jurídico, a infraestrutura do sistema prisional feminino representa um dos maiores empecilhos para a existência das condições necessárias para o adequado 
cumprimento da pena privativa de liberdade. A evidência desse quadro se dá pela inexistência de unidades prisionais construídas para a população feminina e, pela escancarada e ampla utilização de cadeias públicas e delegacias de polícia que, embora destinadas e apropriadas para detenções de curto período e em caráter provisório, são recorrentemente utilizadas para cumprimento de penas longas pelas mulheres no Brasil.

Informações do Departamento Penitenciário Nacional revelam que há apenas 58 presídios no país que se destinam apenas à detenção de mulheres, sendo a $75 \%$ do número total de estabelecimentos existentes voltados exclusivamente ao público masculino. Desta forma, quase todos os estabelecimentos penais em que elas se encontram detidas são mistos, e nelas são adaptadas alas e celas para as mulheres, sem qualquer tipo de tratamento diferenciado voltado para estas.

Vale ressaltar, que a maior parte das poucas penitenciárias femininas existentes estão localizadas em prédios "reformados". Ou seja, eram penitenciárias masculinas, cadeias públicas, ou, ainda, prédios públicos em condições de desativação. Verifica-se, então, que o sistema penitenciário foi pensado pelos homens e para os homens, e as mulheres encarceradas são relegadas a segundo plano. Neste contexto, a superlotação e outras formas de violação dos direitos das presidiárias são recorrentes no seu dia-a-dia.

A pesquisa realizada pela Pastoral Carcerária verificou que no estado do Pará a penitenciária feminina é um antigo Centro de Reeducação de Menores, que ainda mantém as mesmas instalações e estruturas arquitetônicas da época de sua construção. ${ }^{30}$ Já no Distrito Federal, a Penitenciária Feminina também consiste num antigo Centro de Menores Infratores que, porém, passou por uma adaptação em 1997 para abrigar mulheres, contando hoje com duas alas, uma para as presas sentenciadas e outra para as presas provisórias.

\footnotetext{
${ }^{30}$ CEJIL, Centro pela Justiça e pela Justiça Internacional et al. Relatório sobre as mulheres encarceradas no Brasil. Rio de Janeiro,2007. p.20 Disponível em: http://carceraria.org.br/wpcontent/uploads/2013/02/Relato\%CC\%81rio-para-OEA-sobre-Mulheres-Encarceradas-no-Brasil2007.pdf Acesso em: 12/10/ 2016
} 
No Rio de Janeiro, na Penitenciária Talavera Bruce, que apresenta uma população de 331 presas e é informalmente considerada a unidade de melhores condições do estado23, foram encontradas alas com superpopulação de até 20 presas em uma única cela e outras em que as celas se encontram com apenas uma presa. Ao analisar o questionário pertinente a essa unidade constata-se a elevada precariedade: a penitenciária tem apenas um banheiro para cada 20 presas e faltam camas nas celas. Segundo as presas informaram, elas próprias têm que comprar os colchões.Em outra realidade, também no Rio de Janeiro, no Presídio Nelson Hungria, as instalações não são adequadas e há superlotação nas celas, existindo aquelas em que o número de presas chega a 50 mulheres.

Uma cadeia com capacidade para 24 pessoas e com uma população de mais de 200 presas, geralmente funciona com o número de carcereiros para uma cadeia de 24 pessoas. $^{31}$ Isso significa que o número de funcionários não acompanhou o crescimento da população prisional feminina. Além disso, faltam viaturas e carcereiros para cumprir qualquer diligência além do transporte ao pronto socorro.

Ao lado da inadequação dos alojamentos das presas, as condições insalubres dessas cadeias se repetem em todos os estados. Há cadeias superlotadas onde as detentas têm de dormir no pátio a céu aberto e celas sem cama, nas quais todas dormem amontoadas no chão, revezando-se para poder esticar as pernas. $^{32}$

O cenário piora e traz situações chocantes quando a maternidade se encontra presente. A infraestrutura dos estabelecimentos deve comtemplar também a questão da maternidade no ambiente carcerário a fim de viabilizar seu exercício. No entanto, o referido cenário representa uma cena de horrores e torna-se quase impossível inserir de maneira saudável e humanizada a maternidade neste contexto.

\footnotetext{
${ }^{31}$ Ibid. p.32

${ }^{32}$ QUEIROZ, Nana . Disponível em: http://folhanobre.com.br/2016/03/08/descubra-como-e-vidadas-mulheres-nas-penitenciarias-brasileiras/23761. Acesso em: 11/11/2016.
} 


\subsection{Saúde Materno- Infantil}

A saúde, conforme seu conceito institucional trazido pela Constituição Federal Brasileira, é um direito de todos, incluídas as mulheres privadas de liberdade, sendo o Estado seu principal e único garantidor. Entretanto, a definição do instituto revela-se um tanto quanto complexa. Conforme enfatiza a Organização Mundial de Saúde, esta é "um estado de completo bem-estar físico, mental e social, e não consiste apenas na ausência de doença ou de enfermidade" ${ }^{33}$.Desta forma, a adoção de uma concepção ampliada sobre a saúde pressupõe que sejam levados em consideração as determinantes sociais inerentes à cada indivíduo, as quais são os fatores sociais, econômicos, culturais, éticos/raciais, psicológicos, e comportamentais que influenciam a ocorrência de problemas de saúde e seus fatores de risco na população. ${ }^{34}$ Assim, considera-se que todos estes aspectos interferem diretamente no estado de saúde de cada indivíduo.

No tocante à saúde da população prisional feminina, além das situações de descaso e falência similares às vivenciadas nas unidades prisionais masculinas, esta apresenta diversas especificidades do próprio gênero que, no contexto do encarceramento, incidem com intensidade diferenciada se agravando por meio do não acesso a práticas de prevenção, tratamento e devido acompanhamento médico.

Em todo mundo as penitenciarias femininas são vistas como um grave problema público de saúde por reunirem uma parcela da população especialmente vulnerável a doenças infectocontagiosas. ${ }^{35}$ Neste contexto, as más condições de habitabilidade, superpopulação e a insalubridade são

\footnotetext{
33 OMS, Organização Mundial da Saúde. Constituição da Organização Mundial da Saúde (OMS/WHO $\quad-\quad 1946 . \quad$ USP. $\quad$ p.1 http://www.direitoshumanos.usp.br/index.php/OMS-Organização-Mundial-da-Saúde/constituicaoda-organizacao-mundial-da-saude-omswho.html Acesso em: 10/11/2016.

${ }^{34}$ BUSS, Paulo Marchior; FILHO, Alberto Pellegrini. A Saúde e seus Determinantes Sociais Revista Saúde Coletiva Physis. 2007. p.2 Disponível em: http://www.scielo.br/pdf/physis/v17n1/v17n1a06.pdf. Acesso em: 12/11/2016

${ }^{35}$ CARVALHO, Maria Lazaro et al. Perfil dos internos no sistema prisional do Rio de Janeiro: especificidades de gênero no processo de exclusão social. In: Ciência e Saúde Coletiva. 2006 AbrJun; 11(2) p.461. Disponível em: http://www.scielo.br/pdf/csc/v11n2/30433.pdf Acesso em: $10 / 11 / 2016$
} 
fatores que contribuem para a incidência de diversas doenças, enquanto o cenário de baixa estima alimenta doenças de âmbito emocional como a depressão e a angustia.

Quando a gravidez está presente entre as condições biológicas de uma mulher privada de sua liberdade, a manutenção da saúde - objetivando seu bem-estar físico, mental e social - se torna um desafio ainda mais complexo. Durante a gravidez, a mulher passa por mudanças de extrema significância, as quais se intensificam no ambiente prisional e afetam diretamente não só sua saúde, mas também do filho que está ainda em formação e depende diretamente de seu bem-estar.

Neste sentido, Santos afirma que:

“O embrião ou feto reage não só às condições físicas da mãe, aos seus movimentos psíquicos e emocionais, como também aos estímulos do ambiente externo que a afetam. O cuidado com o bem-estar emocional da mãe repercute no ser que ela está gestando" 36

Os cuidados biológicos são essenciais para uma gravidez saudável, no entanto, a dimensão psicológica não pode ser deixada de lado. Sem a devida estrutura para atender suas necessidades como mulher e mãe, o ambiente prisional pode se tornar uma ameaça constante à saúde mental da detenta, acarretando em uma total desestabilização emocional. ${ }^{37}$

No que concerne à assistência médica, o Plano de Saúde no Sistema Penitenciário (PNSSP) prevê entre suas ações especificas a saúde da mulher a realização do pré-natal, garantia do acesso das gestantes ao atendimento de intercorrências, partos e assistência ao puerpério, assim como o controle do câncer cervico-uterino e de mama, garantindo encaminhamento, tratamento

\footnotetext{
${ }^{36}$ SANTOS, Marcos Davi dos et al. Formação em pré-natal, puerpério e amamentação: praticas ampliadas. São Paulo: Fundação Maria Cecilia Souto Vidigal, 2014. (Coleção primeiríssima infância; v. 3). p.19

${ }^{37}$ BISPO, Tânia Cristiane Ferreira et al. Gestar e parir na prisão: difíceis caminhos. VII Jornadas Santiago Wallace de Investigación em Antropologia Social. Sección de Antropologia Social. Instituto de Ciencias Antropologicas. Facultad de Filosofia y Letras, UBA, Buenos Aires, 2013. p.08. Disponível em: http://www.aacademica.com/000-063/187.pdf Acesso em: 10/11/2016
} 
das doenças sexualmente transmitíveis, assistência à anticoncepção e imunizações. ${ }^{38}$

Apesar do atendimento pré-natal ser um direito do nascituro e da mãe, assegurado na LEP e no Estatuto da Criança e do Adolescente, o que se observa é a falta do acompanhamento regular. Muitas presas não recebem qualquer atendimento pré-natal e acabam descobrindo serem soropositivas e portadoras de outras doenças transmissíveis apenas na hora do parto. ${ }^{39}$

A precária estrutura, a ausência de profissionais e a falta de equipamento médico são as principais causas para o abandono vivido pela maior parte das mulheres. Na maioria dos presídios inexistem dependências destinadas aos cuidados relacionados à saúde e as enfermarias se resumem a celas improvisadas em que não são observadas as condições sanitárias adequadas.

As equipes médicas, geralmente estão incompletas e o atendimento ocorre em período parcial. O relatório do Departamento Penitenciário Nacional (DEPEN) identificou a atuação de apenas 3.167 profissionais da área de saúde, sendo este número insuficiente para atender à demanda de aproximadamente 622 mil detentos de todos o país ${ }^{40}$. Diversas penitenciárias, como a Penitenciária Nelson Hungria, por exemplo, localizada no Rio de Janeiro, a qual abriga 474 detentas, não possui assistência médica adequada apesar de estar inscrita no referido Plano Nacional de Saúde do governo federal o qual prevê equipes de qualidade mínima de atendimento. ${ }^{41}$

O PNSSP determina que as ações e os serviços de assistência sejam organizados nas unidades prisionais e realizadas por equipes interdisciplinares compostas por clínicos gerais, dentistas e enfermeiros, bem como por médicos especializados como ginecologistas e psiquiatras. Porém, se a escassez de profissionais atinge toda população carcerária, independente

\footnotetext{
38 BRASIL. Ministérios da Saúde e da Justiça. Portaria Interministerial n.1777/GM, de 09 de setembro de 2003. Aprova o Plano Nacional de Saúde no Sistema Penitenciário e define financiamento. Brasília: Ministério da Saúde; 2003

${ }^{39}$ CEJIL. Op. cit., p. 32

${ }^{40}$ BRASIL, Ministério da Justiça, Departamento Penitenciário Nacional. Op. cit., p. 70

${ }^{41}$ CEJIL. Op. cit., p. 29
} 
do gênero, as mulheres são as mais afetadas vez que precisam de assistência especializada. O número de médicos ginecologistas é desproporcional se comparado à população carcerária feminina e, segundo os dados do INFOPEN, cada profissional atende, em média, a um grupo de 2.335 mulheres.42 Tal omissão resulta na inexistência de controle e tratamento de doenças sexualmente transmissíveis, assim como dos exames de rotina de prevenção de câncer ginecológico.

A quantidade de profissionais qualificados não acompanha o ritmo de crescimento da população carcerária e muitas vezes o atendimento, quando necessário é realizado pelo serviço público da cidade onde está localizada a instituição. A alternativa está prevista na Lei de Execução Penal, a qual prevê que, quando o estabelecimento penal não tiver condições de prover assistência medica necessária, esta será prestada em outro local. ${ }^{43}$ Entretanto a falta de profissionais, bem como de veículos e serviços para realização da escolta policial são os maiores obstáculos ao atendimento médico em hospitais ou postos de saúde públicos. A disponibilidade de profissionais da segurança pública é um fator de extrema importância para a promoção da saúde no contexto carcerário. A falta de profissionais capacitados para realização da escolta policial associa-se à falta de profissionais de saúde, inviabilizando qualquer ação de saúde.

À gestantes também é assegurada nutrição adequada, a qual deverá receber orientação sobre aleitamento materno, alimentação complementar saudável e crescimento e desenvolvimento infantil. ${ }^{44} \mathrm{Na}$ gravidez, este é um fator de extrema importância para a saúde da mãe e desenvolvimento do feto, sendo previstas alterações na dieta da gestante como parte do protocolo da assistência pré-natal. Uma alimentação adequada tem papel importante no

\footnotetext{
${ }^{42}$ INFOPEN. Sistema carcerário nacional tem apenas 15 ginecologistas para 35 mil mulheres presas. Veiculado pelo Ministério da Justiça, dezembro de 2012. Disponível em: http://www.cnj.jus.br/noticias/cnj/25949:sistema-carcerario-nacional-tem-apenas-15ginecologistas-para-35-mil-mulheres-presas. Acesso em: 10/11/2016

${ }^{43}$ BRASIL. Lei de execução Penal. Lei no 7210 de 11 de julho de 1984. Art. 14 §2

${ }^{44}$ BRASIL. Lei federal no 8069, de 13 de julho de 1990. Estatuto da criança e do adolescente. Art. $8 \S 7$.
} 
período gestacional, influenciando na lactação materna, bem como no crescimento da criança e seu desenvolvimento das funções neurais, comportamentais e no risco de ocorrência de morbimortalidade. ${ }^{45}$ Entretanto, a alimentação precária, tanto em sua quantidade como em sua qualidade, também afeta a saúde das mulheres em estado gestacional. Em geral, a alimentação oferecida é inadequada e insuficiente aos quesitos nutricionais para essa mulher, como enfatiza o depoimento de uma gestante alojada em um Conjunto penal Feminino da Bahia:

“[...] alimentação não é tão boa pra gente que precisa comer fruta, não vem, não tem aquela alimentação saudável a gente não tem, tá muito ruim, não vou mentir, tá horrível!. "46

Em um outro estudo realizado na mesma penitenciária, constatou-se que, das três mulheres grávidas presas entrevistadas, nenhuma atendia aos critérios indicados para manter a eficiência alimentar na gravidez e uma delas afirmou que durante a gestação a família não possuía condições financeiras de alimentos para complementar a oferecida pelo presídio. ${ }^{47}$

A assistência psicológica também está assegurada pela LEP às presidiárias gestantes e mães, no período pré e pós-natal, inclusive como forma de prevenir ou minorar as consequências do estado puerperal.48 Em contrapartida, a falta de médicos psicólogos e a escassez de medicamentos novamente assombram a saúde da mães nos presídios.

O ambiente prisional concentra um grande número de mulheres que necessitam de acompanhamento médico por apresentarem algum comprometimento mental, principalmente pelo uso de drogas. Além disso, os fatores presentes no cotidiano das penitenciarias podem contribuir em grande

\footnotetext{
${ }^{45}$ BARROS, Denise Cavalcanti. O Consumo alimentar de gestantes adolescentes no Município do Rio de Janeiro. Rio de Janeiro. 2012. Tese de Pós Graduação. Fundação Oswaldo Cruz. p. 11 Disponível em: http://teses.icict.fiocruz.br/pdf/barrosdcm.pdf Acesso em: 10/11/2016

${ }^{46}$ ARAÚJO, Aparecida do Nascimento Vieira et al. Percepção de Mães Presidiárias sobre os Motivos que Dificultam a Vivência do Binômio. Bahia. 2014. Monografia - Núcleo de Pesquisa Saúde e Violência da Universidade do Estado da Bahia - UNEB. p.6

${ }^{47}$ SOUZA, Jorge Gauthier Santos. Mães, filhos e cárcere: O nascimento atrás das grades. Salvador. 2009. Monografia - Universidade Federal da Bahia. p.22

${ }^{48}$ BRASIL. Lei federal no 8069, de 13 de julho de 1990. Estatuto da criança e do adolescente. Art. $8 \S 4$
} 
parte, para o comprometimento da saúde mental dos indivíduos que ali convivem, principalmente para as mulheres em exercício da maternidade. A precária estrutura prisional, a exposição a doenças, o abandono familiar e a tensão resultante da expectativa da partida da criança são alguns dos fatores que, constantemente, resultam em quadros de adoecimento mental.

A saúde mental acaba comprometida também por conta do aspecto social, vez que o fato de estarem grávidas acarreta afastamento das atividades dentro do presídio e as gestantes e mães experimentam o completo ócio. A falta de meios que proporcionem uma vida saudável, como a oportunidade de exercer o trabalho ou outras atividades dentro do presídio afetam a saúde destas mulheres. Tal realidade é preocupante e demonstra a real incapacidade ressocializadora das penas no Brasil, que se reduzem à mera punição à mulher e ainda viola o direito universal ao acesso à educação e trabalho, assegurado pela própria Constituição Federal de 1988. ${ }^{49}$

A deficiência da atenção à saúde nos mais diversos aspectos - físico, mental e social - representa uma das principais violações às quais as mulheres estão submetidas, principalmente as que vivenciam a maternidade. Existem falhas de toda ordem, mas que convergem em um mesmo sentido: o descaso total às presidiárias e crianças por parte das autoridades.

\subsection{Direitos Maternos- Reprodutivos}

\section{a. Direito de amamentar e ser amamentado}

Dentre os direitos humanos assegurados expressamente pela Constituição Federal, estão o direito das mulheres encarceradas de permanência com seus filhos durante a fase de amamentação e o direito social à proteção da maternidade e da infância.

É o que dispõem os artigos $5^{\circ}$, inciso L, e o caput do artigo $6^{\circ}$, ambos da Carta Magna:

\footnotetext{
${ }^{49}$ BRASIL. Constituição da República Federativa do Brasil de 1988. Art.6
} 
"Art. $5^{\circ}$. Todos são iguais perante a lei, sem distinção de qualquer natureza,
garantindo-se aos brasileiros e aos estrangeiros residentes no País a inviolabilidade
do direito à vida, à liberdade, à igualdade, à segurança e à propriedade, nos termos
seguintes:
L - às presidiárias serão asseguradas condições para que possam permanecer com
seus filhos durante o período de amamentação".

"Art. 6. São direitos sociais a educação, a saúde, a alimentação, o trabalho, a moradia, o lazer, a segurança, a previdência social, a proteção à maternidade e à infância, a assistência aos desamparados, na forma desta Constituição".

Em nível infraconstitucional, tal exigência é trazida pela Lei de Execução Penal, a qual teve as redações de seus artigos alteradas pela Lei n. 11.942 de 2009, a fim de assegurar, expressamente, às mulheres presas o direito de cuidar e amamentar seus filhos por, no mínimo, seis meses após seu nascimento, prevendo ainda a obrigatoriedade das penitenciárias disporem de espaços destinados e adequados ao acolhimento de gestantes e parturientes:

\footnotetext{
“Art. 83. §2 $2^{\circ}$. Os estabelecimentos penais destinados a mulheres serão dotados de berçário, onde as condenadas possam cuidar de seus filhos, inclusive amamentálos, no mínimo, até 6 (seis) meses de idade".
}

“Art. 89. Além dos requisitos referidos no art. 88, a penitenciária de mulheres será dotada de seção para gestante e parturiente e de creche para abrigar crianças maiores de 6 (seis) meses e menores de 7 (sete) anos, com a finalidade de assistir a criança desamparada cuja responsável estiver presa. "

No mesmo sentido dispõe o Estatuto da Criança e do Adolescente ${ }^{50}$ ao prever o dever das instituições de propiciar condições adequadas ao aleitamento materno, inclusive aos filhos de mães privadas de sua liberdade. Assim, de acordo com a legislação vigente, é possível notar que o legislador, ao reconhecer a importância da relação materna, principalmente no delicado período de amamentação, optou pela manutenção das crianças no cárcere, para que permaneçam na companhia de suas mães, durante, pelo menos, os primeiros meses de vida.

Para tanto, a lei determina que os estabelecimentos penais destinados a mulheres serão dotados de berçário, onde as condenadas possam cuidar de

\footnotetext{
${ }^{50}$ BRASIL. Lei federal no 8069 , de 13 de julho de 1990. Estatuto da criança e do adolescente. Art.9.
} 
seus filhos, inclusive amamentá-los até no mínimo seis meses de idade. Entretanto, a importância do contato entre a mãe e seu filho vai muito além do período de amamentação, estendendo-se aos seus primeiros anos de vida.

\section{b. Convivência familiar e manutenção dos vínculos}

Após o nascimento de uma criança, todas as vivências são importantes, mas o relacionamento afetivo entre mãe e filho é o mais primitivo, influenciando diretamente no desenvolvimento psíquico e na formação da personalidade da criança. A relação mãe e filho é indissociável e a dependência de tal vínculo é forte e recíproca. De um lado temos a maternidade: o instinto materno mais primitivo. Do outro, a fragilidade de uma criança, a qual depende inteiramente de sua genitora para sobreviver.

Bowlby $^{51}$ afirma que a angústia da privação do vínculo materno pode atingir de maneira importante a formação da saúde mental da criança, podendo comprometer a afetividade e os posteriores relacionamentos desta. O autor refere que a consequência dessa privação "pode desencadear comportamentos agressivos e delinquentes".

Ainda sobre o tema, o autor ${ }^{52}$ defende que "o primeiro e o mais persistente de todos os vínculos é o entre mãe e filho pequeno, que frequentemente persiste até a idade adulta. Cada membro deste par vinculado tende a manter-se na proximidade do outro e a suscitar, no outro, o comportamento de manutenção da proximidade."

Reconhecida sua importância, com o passar do tempo, a questão passou a receber maior atenção. A Lei ${ }^{\circ}$ 11.942, de 27 de maio de 2009, além do tempo mínimo de para a amamentação, busca garantir a extensão desta convivência, prevendo a existência de uma seção para gestantes e

\footnotetext{
${ }^{51}$ BOWLBY, John. Apud STELLA, Cláudia. Filhos de mulheres presas: soluções e impasses para seus desenvolvimentos. São Paulo: LCTE Editora, 2006. p.46.

${ }^{52}$ BOWLBY, John. Apud KUROWSKI, Cristina Maria. Análise crítica quanto a aspectos de implantação e funcionamento de uma creche em penitenciária feminina. Porto Alegre, 1990. p.14
} 
parturientes, bem como creche para crianças menores de sete anos desamparadas, cuja responsável esteja presa.

Ainda no mesmo ano, o Conselho Nacional de Política Criminal e Penitenciária -CNPCP emitiu a Resolução $n^{\circ}$ 04, a qual fornecia dentre suas instruções:

Art. $1^{\circ}$ A estada, permanência e posterior encaminhamento das (os) filhas (os) das mulheres encarceradas devem respeitar as seguintes orientações:

(...)

II - Continuidade do vínculo materno, que deve ser considerada como prioridade em todas as situações.

As mudanças legislativas nacionais e os acréscimos internacionais buscaram garantir não só dos direitos das presas, mas principalmente de seus filhos. Claramente, podê-se observar a priorização da convivência familiar, em consonância com a doutrina da proteção integral da criança.

Vale ressaltar que os frutos da relação mãe-filho não influenciam somente a criança. A própria experiência da gravidez e o exercício da maternidade são responsáveis pela ocorrência de diversas mudanças na vida de uma mulher. Os sentimentos experimentados, bem como as mudanças emocionais e comportamentais sofridas durante o período trazem novas perspectivas e influenciam diretamente no estímulo para a reabilitação.

A importância do relacionamento mãe-filho somente destaca o papel do Estado como garantidor de direitos dentro das penitenciárias, cabendo a este a adequação de tais instituições para que estas sejam capazes de abrigar crianças, priorizando seu desenvolvimento pleno e saudável. A LEP, nestes termos, prevê que a estadia da criança pode prolongar-se até os seus sete anos de idade, na hipótese desta não ter outra pessoa, além da mãe, para responsabilizar-se por ela. ${ }^{53}$ No entanto, tal período de permanência não é claramente pautado pela legislação, o que resulta em dúvidas e insegurança para determinar qual seria o período de amamentação e, posteriormente, o tempo de separação da mãe e seu bebê, ou ainda quanto tempo uma criança deveria permanecer em um ambiente prisional.

\footnotetext{
${ }^{53}$ BRASIL. Lei de execução Penal. Lei no 7210 de 11 de julho de 1984. Art.89.
} 
Diante de tal generalidade da lei, o referido período sofre variações de acordo com cada Estado, a depender das estruturas físicas de seus presídios e, muitas vezes, da determinação dos diretores de tais estabelecimentos, conforme trata o Promotor de Justiça José Heitor dos Santos:

\begin{abstract}
“(..) trata-se de um desdobramento do princípio mais amplo de que a pena não pode passar da pessoa do réu. Para que a amamentação se torne possível, é necessário que as cadeias e presídios femininos dispensem condições materiais para que se possa levá-la a efeito. A Constituição Federal e as leis infraconstitucionais asseguram esse direito e muito embora o dispositivo constitucional faça referência a condições futuras que serão asseguradas, encerra, na verdade, um dispositivo de aplicabilidade imediata, pois as providências nele referidas não chegam a exigir qualquer medida legislativa. Não é muita coisa o que se exige para o cumprimento do dispositivo. Não é nada, na verdade, que não possa ser alcançado dentro da esfera de competência da própria diretoria do estabelecimento penitenciário. “54
\end{abstract}

Apesar de haver a possibilidade, em algumas unidades, da criança permanecer por um período de amamentação de até 6 meses ou mais, a separação entre mãe e filho ocorre inevitavelmente. Segundo os dados colhidos pela Pastoral Carcerária nas unidades prisionais do Espírito Santo (Penitenciária Estadual Feminina), Distrito Federal (Penitenciaria Feminina), Bahia, Amapá há informações que as crianças podem permanecer até seis meses com suas mães. No Rio Grande do Sul (Penitenciária Feminina Madre Pelletier), as crianças podem permanecer até os 3 anos de idade, já no Rio de Janeiro (Instituto Materno Infantil), até 12 meses. Já no Estado do Amazonas, as mães podem ficar com os filhos apenas 15 dias após o seu nascimento e em Pernambuco até 10 meses.

Importante salientar que muitas vezes é incerto o destino dessas crianças e o vínculo familiar não se sustenta ao longo do tempo em que a mãe está detida.Para aquelas crianças que não possuem responsáveis fora da prisão e serão abrigadas, a lei estabelece que a escolha do abrigo deve ser realizada pelas mães assistidas de profissionais qualificados, mas devendo sempre a família original ser priorizada. Por isso, crianças de até sete anos de

\footnotetext{
54 SANTOS, José Heitor. Aleitamento materno nos presídios femininos. Disponível em: http://www.mp.rs.gov.br/infancia/doutrina/id103.htm;http://www.mp.rs.gov.br/infancia/doutrina/id 103.htm>. Acesso em 30/10/2016
} 
idade, cuja única responsável seja a mãe que se encontra presa, podem permanecer com as mães na unidade prisional, desde que a penitenciária possua local materno infantil. ${ }^{55}$ Isso significa que o Estado, além de atender as necessidades das mulheres encarceradas, deverá atender também às necessidades das crianças que terão, durante parte de sua vida, uma penitenciária como lar.

No entanto, a ausência de determinação legal acerca do período de permanência da criança no ambiente prisional, bem como sobre as instalações das creches e berçários, resultam em padrões próprios, estabelecidos por cada Estado, a depender da estrutura física dos presídios e, muitas vezes, da determinação dos diretores dos estabelecimentos.

O momento de separação é sempre doloso e esta deve ocorrer com a análise de cada caso individualmente, considerando a peculiaridade de cada criança, conforme previsto na Regra $\mathrm{n}^{\circ} 52$ - Bangkok. Além disso, com o intuito de preservar o bem-estar da criança e causar o menor impacto psicológico possível, os procedimentos necessários para a separação deverão ser conduzidos com delicadeza e cuidado, como estabelece o art. $3^{\circ}$ da Resolução nº 04/2009, do CNPCP.

A legislação prioriza o acolhimento dessas crianças por membros da sua família - como avós ou outros parentes. A colocação em família substituta, através do encaminhamento da criança à uma instituição de adoção, deve aparecer como última medida e somente poderá ocorrer por meio de decisão judicial, desde que comprovada como a melhor possibilidade e esgotadas todas as demais.

Após a separação, o contato entre mãe e filho permanece sendo um direito de ambos, salvo expressa e fundamentada determinação em contrário. Tal convivência, mesmo após a separação, é assegurada pelo Estatuto da Criança e do Adolescente, por meio de visitas periódicas promovidas pelo 
responsável ou, nas hipóteses de acolhimento institucional, pela entidade responsável, independentemente de autorização judicial. ${ }^{56}$

Mais do que garantida, tal convivência deve ser estimulada ao máximo. Uma vez separadas as crianças de suas mães e colocadas com familiares ou parentes, ou outra forma de abrigo, às mulheres presas será dado o máximo de oportunidade e será facilitado o encontro entre elas e as crianças, quando for no melhor interesse das crianças e a segurança pública não estiver comprometida. ${ }^{57}$ Para tanto, todos os aspectos citados devem ser reconhecidos e valorizados, a fim de evitar que tal vínculos venham a ser romper frente as dificuldades e desafios que venham permear a convivência familiar entre mulheres privadas de sua liberdade e seus filhos.

\section{c. A experiência da maternidade nas penitenciárias brasileiras}

Apesar da expressa previsão da LEP, a existência de cela específica para gestantes, berçário, creche e centro de referência materno-infantil equipamentos e espaços responsáveis por tornar o exercício da maternidade no ambiente prisional minimamente viável - é precária. Menos da metade dos estabelecimentos femininos dispõe de cela ou dormitório adequado para gestantes, enquanto nos estabelecimentos mistos, apenas $6 \%$ das unidades dispunham de espaço específico para a custódia de gestantes. ${ }^{58}$

Já quanto à existência de berçário ou centro de referência materno infantil, aproximadamente um terço das unidades femininas dispunham do espaço, enquanto apenas $3 \%$ das unidades mistas o contemplavam. $\mathrm{Na}$

\footnotetext{
${ }^{56}$ BRASIL. Lei federal no 8069, de 13 de julho de 1990. Estatuto da criança e do adolescente.Art.19 $\S 14$.

57 ONU. Regras de Bangkok. Adotada pela Assembleia Geral em 16/03/11. Resolução A/RES/65/229. p.10. Regra n $52 . \quad$ Disponível em: http://www.cnj.jus.br/files/conteudo/arquivo/2016/03/27fa43cd9998bf5b43aa2cb3e0f53c44.pdf Acesso em: 03/10/2016

${ }^{58}$ BRASIL, Ministério da Justiça, Departamento Penitenciário Nacional, Levantamento nacional de informações penitenciárias - INFOPEN Mulheres - junho 2014 (Brasília: Ministério da Justiça, Depen, 2014). p.18. Disponível em: https://www.justica.gov.br/noticias/estudo-traca-perfil-dapopulacao-penitenciaria-feminina-no-brasil/relatorio-infopen-mulheres.pdf Acesso em: 10/10/2016
} 
maioria das unidades prisionais, o berçário é uma cela improvisada, com as mesmas características de insalubridade comuns a esses locais.

Em relação à existência de creches, o número é ainda mais assustador: apenas $5 \%$ das unidades femininas dispõem de creche, não sendo registrada nenhuma creche instalada em unidades mistas.

Os dados colhidos mostram que, somente no ano 2006, vários partos foram realizados nos pátios ou nas celas das unidades prisionais, alguns, inclusive, na viatura policial a caminho do hospital. Devido a tais condições, há muitos registros de óbitos de recém-nascidos.

$\mathrm{Na}$ prática, a amamentação ocorre, mas quase sempre de forma incorreta. É recorrente o desrespeito quanto aos direitos dessas mães e, principalmente, de seus bebês. É necessário propiciar um ambiente agradável e tranquilo para que a experiência seja benéfica à esta criança, o que não condiz com a realidade vivenciada por essas presidiárias. Quando as presas não são obrigadas a passar o tempo com seus filhos em celas - muitas vezes compartilhadas -, o exercício deste direito ocorre de forma prejudicial nos estabelecimentos que possuem alas especiais destinadas à convivência entre mãe e filho.

Por falta de berçário adequado, as unidades prisionais que tentam garantir a amamentação, muitas vezes acabam colocando mães e seus bebês em situações subumanas, como a CPI do Sistema Carcerário apontou em Recife: "vimos um bebê de somente seis dias dormindo no chão, em cela mofada e superlotada, apenas sobre panos estendidos diretamente na laje".59

A atual situação das "creches" é extremamente inadequada, tanto para as mães, quanto para seus filhos. As crianças encontram-se em um local úmido, sujeitas às brigas que ocorrem entre as detentas e a um ambiente totalmente hostil, que apesar de ser diferenciado do restante da penitenciária,

${ }^{59}$ CENTRO PELA JUSTIÇA E PELO DIREITO INTERNACIONAL et al. Relatório sobre Mulheres Encarceradas no Brasil, p. 32. Disponível em: http://www.carceraria.org.br/wpcontent/uploads/2012/09/relatorio-mulherese-presas_versaofinal1.pdf. Acesso em: 08/11/2016 
não perde seu caráter institucional e seu perfil prisional. ${ }^{60} \mathrm{O}$ confinamento da mãe e a condição de dar à luz a um filho que permanecerá "preso" durante seus primeiros meses de vida provocam reações diversas nas presas e expressam o antagonismo existente entre o ambiente de privação de liberdade e o processo de geração de uma nova vida.

No que tange o fator psíquico, a experiência se torna uma outra espécie de punição. Durante o período de convivência entre mães e bebês na unidade prisional, estas exercem uma "hipermaternidade", onde a permanência ininterrupta com a criança é a regra no tempo de convivência permitido, sendo esse período permeado pelo rigor disciplinar e tutela do exercício da maternidade. A presença ininterrupta durante o período de convivência entre mãe e bebê nos primeiros meses após o parto, mesclada à constante expectativa de ruptura, a qual, na maioria das vezes ocorre sem qualquer acompanhamento psicológico, é um dos dramas vividos por essas mães.

Os relatos das mães transparecem a constante angustia vivida enquanto aguardam a súbita ruptura da convivência com seu bebe. Esse é o caso de Lucinéia, presidiária alojada na penitenciária "Dra.Marina Marigo Cardoso de Oliveira, conhecida como Butantã, em São Paulo, a qual conta com ala especial para mães e bebes até seis meses:

"Todo o dia eu acordo com medo de ser o dia de levarem minha filha. Quando chega às $17 \mathrm{hs}$ fico aliviada, terei mais uma noite com ela." ${ }^{61}$

Quando a convivência cessa e a criança é retirada do convívio materno, sendo entregue para algum familiar ou encaminhada para um abrigo, ocorre o rompimento imediato do vínculo materno, sem transição ou qualquer período de adaptação. Isso significa que a vivencia é rompida, mas

\footnotetext{
${ }^{60}$ PEREIRA, Larissa Urruth. Do berço à cela - A Extensão das Penas na Penitenciária Feminina Matic Pelletier. Disponível em: http://www.publicadireito.com.br/artigos/?cod=eca336bc46296c1a Acesso em: 10/11/2016

${ }^{61}$ BRAGA, Ana Gabriela Mendes; ANGIOTTI, Bruna. Da Hipermaternidade à Hipomaternidade no Cárcere Feminino Brasileiro.2015. Revista Internacional de Direitos Humanos. SUR 22 - v.12 n.22. p.234 Disponível em: http://sur.conectas.org/wp-content/uploads/2015/12/16_SUR22 PORTUGUES ANA-GABRIELA-MENDES-BRAGA BRUNA-ANGOTTI.pdf Acesso em: $20 / 10 / 2016$
} 
os instintos primordiais da maternidade seguem no corpo e na mente da presa. Os inúmeros relatos de remédios para secar o leite, de "febre emocional", de "desespero" ao ouvir o choro de outras crianças, evidenciam que a maternidade segue no corpo.3 As expectativas e o medo da separação definitiva, são experiências marcantes trazidas pela brutalidade da ruptura.

É possível, ainda, verificar hipóteses ainda mais graves de ruptura do vínculo materno, onde o encarceramento interrompe de forma definitiva qualquer possibilidade de exercício da maternidade por parte da mulher presa e da manutenção de qualquer vínculo familiar. São os casos em que as crianças são encaminhadas para abrigos ou, em alguns casos, para adoção.

Apesar da Lei $n^{\circ}$ 12.962/14 ter assegurado a convivência de crianças e adolescentes com mães e pais privados de liberdade, prevendo explicitamente que condenação criminal do pai ou da mãe não implicará a destituição do poder familiar e que criança será mantida em sua família de origem, muitos são os casos em que as mães sequer tem conhecimento do destino de sua criança abrigada e vivem o medo de perdê-los para uma família adotiva.

Após a separação, torna-se ainda mais difícil manter qualquer vínculo. Notório é o número de presas que são mães e que suas filhas estão em guarda provisória com algum parente próximo, geralmente mulheres, e mais especificamente avós maternas. Contudo, muitas dessas mães contaram que veem suas filhas apenas uma vez por mês, enquanto algumas não encontram suas crianças há meses. Os relatos das presidiárias mostram como é comum a perda de contato com seus filhos que, segundo estas, "perde o costume de falar com a mãe"62.

\footnotetext{
62 BRASIL, Ministério da Justiça. Secretaria de Assuntos Legislativos. Dar à luz na sombra: condições atuais e possibilidades futuras para o exercício da maternidade por mulheres em situação de prisão. Brasília: Ministério da Justiça, IPEA,2015.Série Pensando o Direito, n.51. p.42. Disponível em: http://www.justica.gov.br/noticias/201clugar-de-crianca-nao-e-na-prisao-nemlonge-de-sua-mae201d-diz-pesquisa/pesquisa-dar-a-luz-na-sombra-1.pdf. Acesso em: 10/11/2016.
} 


\subsection{Obstáculos na manutenção dos vínculos familiares e afetivos}

A pena restritiva de liberdade acaba estendendo seus efeitos à família das presidiárias, em especial aos seus filhos. Um dos aspectos negativos mais incidentes nas vidas das mulheres presas é o distanciamento da família, diferentemente da realidade vivenciada pelos homens presos, os quais em geral mantém seus vínculos familiares durante o período de encarceramento.

Primeiramente, é relevante considerar a estigmatização social vivida pela mulher que “delinquente”. Tal estigmatização, por sua vez, dá-se, indiscutivelmente, pela herança histórica das sociedades patriarcais, que apregoava a submissão e recato feminino, logo as mulheres que contrariam tal premissa são punidas e marginalizadas socialmente, fator que contribui decisivamente para o abandono da presidiária pela família e amigos ${ }^{63}$.

Desta forma, é recorrente o abandono das mulheres presas, em um primeiro momento por seus companheiros, que rapidamente estabelecem novas relações afetivas, e também por seus familiares, que por motivos variados não se dispõem a realizar a visita. Essa realidade é verificada nos dias de visita, nos quais as filas nas instituições fechadas destinadas aos homens são extensas, enquanto as filas em dia de visita nas penitenciárias femininas são bastante reduzidas.

Um dos fatores que contribuem para o isolamento destas mulheres e inviabilizam a assiduidade das visitas diz respeito à distância física entre as unidades prisionais e as residências de amigos e familiares das presas. Considerando que o número de unidades prisionais femininas é reduzido, ocorre uma concentração da população prisional feminina em poucas unidades as quais, na maioria dos casos, estão muito longe de seus locais de origem. Sendo assim, a distância associada ao custo financeiro do transporte

\footnotetext{
63 Ministério da Justiça. Secretaria Especial de Política para as Mulheres. Reorganização $e$ reformulação do sistema prisional feminino: Relatório final. 2007. p.90 Disponível em: <http://portal.mj.gov.br/depen/main.asp?ViewID=\%7B71FD341F-0531-4BAB-A56772586745CB18\%7D\&params=itemID=\%7B0892E0A1-29D4-4E56-AF956B4B6EC869A2\%7D;\&UIPartUID=\%7B2868BA3C-1C72-4347-BE11-A26F70F4CB26\%7D Acesso em: 07/11/2016
} 
acabam por desincentivar as visitas e constituem entraves à vivencia familiar. É comum presidiárias afirmarem que as despesas com o deslocamento para a visita pesam no orçamento familiar.

A restrição dos horários de visita também dificulta a frequência da mesma. Existem presídios, por exemplo, que estabelecem que a visita ocorrerá somente nos dias úteis, o que impossibilita o exercício desta pela a maioria das pessoas, vez que estas trabalham e muitas vezes não podem dispor do tempo necessário.

Outro fator existente é a revista íntima, que é um requisito para o ingresso do familiar na unidade prisional, mas considerada por familiares e amigos como uma experiência extremamente humilhante. Este procedimento causa em muitos dos visitantes um sentimento de violação em sua dignidade, pois se veem física e psicologicamente invadidas em sua intimidade visto que é necessário expor partes intimas de seu corpo a estranhos ${ }^{64}$.Apesar de reconhecida pelas autoridades públicas como necessária, a revista vexatória representa uma forma de transmissão da pena da pessoa presa aos seus amigos e familiares, ou seja, pessoas inocentes, de forma causar-lhe forte constrangimento. Nem as crianças, gestantes ou idosas escapam da revista intima, a qual, muitas vezes, é realizada sem qualquer privacidade, ocorrendo na frente de desconhecidos.

A Pesquisa realizada pela Pastoral Carcerária em unidades prisionais femininas em diferentes Estados brasileiros ${ }^{65}$ constatou que ao longo dos dois últimos anos, na Penitenciária Estadual Feminina de Tucum, a única penitenciária feminina do estado do Espírito Santo, 50\% das mulheres presas não recebem visitas; Já no Presídio Nelson Hungria, localizado no Rio de Janeiro, menos de um terço das mulheres recebem visitas. Enquanto isso, no Complexo Penitenciário no Estado do Amazonas, onde o transporte é precário, apenas $50 \%$ das detentas eram visitadas por seus familiares.

\footnotetext{
${ }^{64}$ COLMEIA, Z. Família e Cárcere: os efeitos da punição sobre a unidade familiar e a necessidade de inclusão. Boletim do Centro de Apoio Operacional das Promotorias Criminais, do Júri e de Execuções Penais - Área de Execução Penal no 86 -maio/2011. p.13

${ }^{65}$ CENTRO PELA JUSTIÇA E PELO DIREITO INTERNACIONAL et al. Relatório sobre Mulheres Encarceradas no Brasil. 2007.p.41
} 
Nesse sentido, a sensação de solidão é compreendida e referida pelas mulheres presas, visto que, o abandono e distanciamento da família são praticamente inevitáveis neste contexto. A entrevista realizada em um penitenciária da Paraíba ${ }^{66}$, revela o sofrimento e sentimento de abandona experimentado por uma das presidiárias:

"É um sofrimento e uma saudade muito grande, ficar aqui sem receber visita da família (Choro). É muito triste ficar aqui abandonada, sozinha e sem a família, por isso temos que dar valor a família da gente."

O próprio ambiente penitenciário, reconhecido por sua hostilidade, o qual envolve a superlotação e agressões também contribui negativamente para o abandono dessas mulheres, o que é evidenciado na fala de outra presidiária:

"Acho que o ambiente da prisão não ajuda ninguém a nada. Aí também o ambiente não ajuda a gente a ter uma convivência com a família. Nem ajuda as mães que estão presas a conviver com seus filhos... Aí os filhos abandonam as mães...”

A questão da visita intima também deve ser evidenciada, vez que o direito não é garantido na maioria dos estabelecimentos prisionais femininos. Esta, quando não totalmente vedada - como ocorre em algumas unidades prisionais -, está condicionada a alguns requisitos, como a comprovação de parentesco, ou são concedidas em condições inadequadas sem a privacidade devida. Em uma breve comparação com as condições do encarceramento masculino, pode-se constatar a existência de uma gritante disparidade e discriminação na efetiva concessão do direito a visita íntima, a qual ocorre com muito mais facilidade, flexibilidade e frequência nos presídios masculinos.

A Pesquisa Dar a Luz na Sombra ${ }^{67}$ relata que, segundo as encarceradas, não há um local apropriado para a realização da visita íntima e

\footnotetext{
${ }^{66}$ JESUS, Amanda Costa Freitas et al. O significado e a vivência do abandono familiar para presidiárias. In: Ciência e Saúde. Jan.-abr.2015;(8):19-25.p.22 Disponível em: http://revistaseletronicas.pucrs.br/ojs/index.php/faenfi/article/view/19535. Acesso em: 08/10/2016

${ }^{67}$ BRASIL, Ministério da Justiça. Secretaria de Assuntos Legislativos. Dar à luz na sombra: condições atuais e possibilidades futuras para o exercício da maternidade por mulheres em situação de prisão. Brasília: Ministério da Justiça, IPEA,2015.Série Pensando o Direito, n.51. p.41.
} 
ocorrem nas próprias celas, sem qualquer forma de privacidade. Nesse contexto, crianças e famílias dividem o espaço com casais, o que contribui para a construção de um clima constrangedor entre as próprias presas.

Diante do exposto, percebe-se que muitos são os empecilhos enfrentados pelas mulheres que se encontram privadas de sua liberdade e por seus amigos e familiares, contribuindo diretamente para seu abandono. Durante a gravidez a mulher experimenta a maternidade de forma completamente isolada, sem o apoio de seus parceiros e familiares. Em seguida, após a separação de seu filho, a maioria das presas vivenciam uma brusca ruptura dos vínculos familiares. Quando as crianças não seguem para algum abrigo, muitas vezes são entregues à suas próprias mães - as avós das crianças - ou a algum outro familiar que dará continuidade aos seus cuidados. Desta forma, estes familiares se tornam a única ligação existente entre as mães e seus filhos, dependendo inteiramente da visita promovida por estes para a manutenção da convivência. O abandono familiar, então, acaba por acarretar uma quebra quase definitiva do vínculo entre mães e filhos que já não vivem mais dentro das grades.

Disponível em: http://www.justica.gov.br/noticias/201clugar-de-crianca-nao-e-na-prisao-nemlonge-de-sua-mae201d-diz-pesquisa/pesquisa-dar-a-luz-na-sombra-1.pdf. Acesso em: 10/11/2016. 


\section{Capítulo 4: O Poder Judiciário como principal gargalo na garantia dos direitos das presas}

\subsection{A cultura brasileira de encarceramento como medida de segurança e o uso abusivo da prisão provisória}

Apesar da existência de normas internacionais vinculantes, derivadas do direito internacional dos tratados, que são muito claras em reconhecer o direito à presunção de inocência e a excepcionalidade da detenção preventiva, bem como do amplo reconhecimento destes direitos no âmbito constitucional, a utilização do instituto da prisão provisória tem ocorrido de forma abusiva no Brasil. Cerca de $40 \%$ da população carcerária brasileira encontra-se em prisão provisória.

"O Brasil é conhecido internacionalmente como um país que extrapola qualquer limite no número de prisões preventivas. É uma prisão que pela Constituição é excepcionalíssima e na prática ela é a regra. No fim das contas, serve como uma forma antecipada de pena e como forma de contenção social mesmo" diz o defensor público e coordenador do Núcleo de Situação Carcerária, Patrick Cacicedo. ${ }^{68}$

Segundo o criminologista Salo de Carvalho "o sintoma contemporâneo vontade de punir, atinge os países ocidentais e que desestabiliza o sentido substancial de democracia, propicia a emergência das macropolíticas punitivistas (populismo punitivo), dos movimentos políticos-criminais encarceradores (lei e ordem e tolerância zero) e das teorias criminológicas neoconservadoras (atuarismo, gerencialismo e funcionalismo sistêmico)”. 69

\footnotetext{
68 CNJ. População carcerária feminina $567 \%$ em 15 anos no Brasil. 2015 Disponível em: http://cnj.jus.br/noticias/cnj/80853-populacao-carceraria-feminina-aumentou-567-em-15-anos-nobrasil. Acesso em: 08/11/2016

${ }^{69}$ CARVALHO, Salo. O papel dos atores do sistema penal na era do punitivismo. Rio de Janeiro: Lumen Juris, 2010 .p.29
} 
O uso excessivo desta medida é contrário à essência do Estado democrático de direito e sua utilização como uma forma de justiça mais célere, da qual resulta uma espécie de pena antecipada, possui inúmeros aspectos negativos. Manter uma grande quantidade de pessoas privadas de liberdade a espera de julgamento acarreta resultados prejudiciais à gestão penitenciária. A aplicação não excepcional desta medida faz com que a população carcerária cresça descontroladamente e represente um alto custo para o Estado. Desta forma, os recursos do sistema penitenciário, que geralmente são escassos, tornam-se insuficientes para atender às necessidades da crescente população reclusa.

Além disso, é possível ainda afirmar que manter uma pessoa sob regime de detenção preventiva por um período prolongado pode, de alguma forma, influenciar na decisão final do juiz, tornando-os mais propensos a prolatar sentenças condenatórias para, de alguma forma, avalizar sua decisão de ter encarcerado o acusado.

Em face do princípio constitucional da presunção de inocência, a prisão preventiva, como qualquer outra medida cautelar pessoal, não pode assumir caráter satisfatório. Ou seja, isso significa que esta não pode se transformar em uma antecipação da tutela penal. Neste mesmo sentido, discorre o autor Aury Lopes Jr.:

"sob a perspectiva do julgador, a presunção de inocência deve(ria) ser um princípio da maior relevância, principalmente no tratamento processual que o juiz deve dar ao acusado. Isso obriga o juiz não só a manter uma posição 'negativa' (não o considerando culpado), mas sim a ter uma postura positiva (tratando-o efetivamente como inocente)." ${ }^{, 70}$

No atual cenário, dentre a população carcerária feminina, 30\% das mulheres encarceradas estão presas provisoriamente, ou seja, ainda aguardando julgamento e $80 \%$ são mães. A maioria delas é a principal ou a única referência de cuidado de seu filho. Ainda assim, essa realidade é praticamente ignorada tanto no momento da prisão quanto na sentença penal

\footnotetext{
${ }^{70}$ LOPES, Aury Jr. Direito processual penal e sua conformidade constitucional. v.1. $5^{\mathrm{a}}$ ed. Rio de Janeiro: Lumen Juris, 2010. p.193
} 
e, na maioria das vezes, sequer há registro no inquérito policial ou processocrime de que a mulher tem filhos ou mesmo de que está grávida.

No que pese toda esta fúria punitiva, como já refletido neste trabalho, o aumento do encarceramento não possui a capacidade de reduzir a criminalidade. Sequer é possível estabelecer qualquer relação direta entre a prática do aprisionamento em massa e a diminuição dos índices de crimes.

O estudo "Saúde Materno-Infantil nos Presídios", feito pela Escola Nacional de Saúde Pública da Fiocruz, entre fevereiro de 2012 a outubro de 2014, mostra que $65 \%$ das gestantes condenadas poderiam cumprir prisão domiciliar, por terem cometido crimes de menor poder ofensivo, como porte de drogas e pequenos furtos, e por serem presas provisórias aguardando julgamento.

\subsection{Prisão domiciliar como alternativa às penas privativas de liberdade}

Ao analisarmos a legislação penal e de execução penal, bem como a sua aplicação, verificamos alguns avanços importantes legislativos e jurisprudenciais, os quais demonstram o despertar de uma preocupação da jurisdição brasileira em relação aos direitos das presidiárias em período de gestação e de seus filhos.

A prisão domiciliar tem previsão legal na Lei de Execuções Penais e admite o recolhimento de beneficiário de regime aberto em residência particular, quando se tratar de condenado maior de 70 anos; acometido de doença grave; condenada com filho menor ou deficiente físico ou mental, ou condenada gestante. ${ }^{71}$ Entretanto, a lei restringe a aplicação da referida medida, a qual somente pode ser aplicada à gestante caso esta tenha sido condenada a regime aberto, e "substitui" o cumprimento da pena em casa de albergado. De todo modo, esta pode e deve ser estendida, independentemente do regime de cumprimento da pena, àquelas mulheres que têm filhos em tenra

${ }^{71}$ BRASIL. Lei no 7210 de 11 de julho de 1984. Lei de execução Penal. Art.117. 
idade ou em fase de amamentação sempre que a unidade prisional não oferecer as condições necessárias à efetivação do convívio familiar entre mãe e filho. Trata-se de uma interpretação guiada pelo fundamento da dignidade humana e pelo da prioridade absoluta à criança.

O instituto também é previsto pelo Código de Processo Penal, o qual prevê a possibilidade de o réu, em vez de ficar em prisão preventiva, permanecer recolhido em sua residência:

Art. 317. A prisão domiciliar consiste no recolhimento do indiciado ou acusado em sua residência, só podendo dela ausentar-se com autorização judicial.

No entanto, diferentemente da anteriormente exposta, a prisão domiciliar neste prevista possui natureza de medida cautelar e substitui a prisão preventiva pelo recolhimento da pessoa em sua residência. Seu cabimento está previsto no artigo seguinte do mesmo código, o qual, anteriormente previa a possibilidade de sua aplicação somente nos casos em que se tratassem de acusadas acima do sétimo mês de gravidez ou gestante em risco.

Recentemente, a Lei nº 13.257, publicada em março de 2016, alterou o referido dispositivo e expandiu as hipóteses em que poderá ocorrer a substituição da prisão preventiva pela prisão domiciliar, além de não mais exigir que a mulher esteja em estado de gravidez de risco ou acima do sétimo mês para que esta seja possível. Assim, o juiz poderá adotar a substituição da medida quando se tratar de gestante - independente do estado ou etapa da gravidez, abrangendo ainda a mulher com filho de até doze anos de idade incompletos.

Conforme Nucci ${ }^{72}$, tais artigos introduziram uma novidade no âmbito do processo penal:

O substituto introduz uma novidade em matéria processual penal, consistente na prisão domiciliar, para fins cautelares. Essa modalidade de prisão somente era conhecida, em nosso sistema, em duas situações: a)não havendo local adequado

\footnotetext{
72 NUCCI, Guilherme de Souza. Prisão e Liberdade. As reformas processuais penais introduzidas pela Lei 12.403, de 4 de maio de 2011. São Paulo: Revista dos Tribunais. $2^{\circ}$ tiragem. p.76
} 
para o cumprimento de prisão especial, nas hipóteses previstas pelo art. 295 do CPP, segue-se o disposto na Lei 5.256/67, instalando-se o detido em prisão domiciliar; b) em caso de condenação em regime aberto, conforme a condição pessoal do sentenciado, pode cumprir em prisão domiciliar, nos termos do art. 117 da Lei de Execução Penal.

É importante salientar que a norma prevê a possibilidade de substituição da prisão preventiva pela domiciliar, mas não assegura à acusada, automaticamente, tal direito diante da presença de um dos pressupostos indicados no artigo. Desta forma, cabe ao juiz decidir pela aplicação, ou não, de tal hipótese, considerando isoladamente cada caso.

A mesma lei, conhecida como Marco Legal de Atenção à Primeira Infância, alterou mais alguns dispositivos do Código de Processo Penal para que as informações sobre a família e fillhos da pessoa presa sejam informadas no auto de flagrante, de maneira a criar mecanismos institucionais para que atores do sistema de justiça, como polícia, ministério público, advogados e juízes estejam atentos à condição de responsável pelo cuidado das crianças, a qual atinge principalmente as mulheres - que, na maioria das vezes, são as principais e únicas responsáveis pela criação da criança.

Dessa forma, tanto a autoridade policial, no momento da prisão, quanto a judiciária, no curso do processo penal, deverão ter informações sobre a existência de filhos, suas respectivas idades, bem como se possuem alguma deficiência. Além disso, a pessoa presa ou acusada ainda poderá fornecer o nome e contato de eventual responsável pelos cuidados dos filhos.

Vale ressaltar ainda, que o ordenamento jurídico brasileiro reconhece a necessidade de não estender os efeitos da condenação aos filhos e familiares, sendo esta positivada na Constituição como direito fundamental ${ }^{73}$, e ainda possibilita, através da interpretação do disposto no Código Penal ${ }^{74}$, que a condição de mãe seja considerada como atenuante ao dispor que " $a$ pena poderá ser ainda atenuada em razão de circunstância relevante, anterior ou posterior ao crime, embora não prevista expressamente em lei."

\footnotetext{
${ }^{73}$ BRASIL. Constituição da República Federativa do Brasil de 1988. Art. 5º XLV.

74 BRASIL. Decreto-Lei 2.848, de 07 de dezembro de 1940. Código Penal. Diário Oficial da União, Rio de Janeiro, 31 dez. 1940. Art. 66
} 
Diante do arcabouço normativo encontrado, é possível afirmar que a legislação brasileira sofreu grandes avanços em relação ao tema. No entanto, as hipóteses de substituição por medidas não privativas da liberdade para mulheres ainda são um tanto quanto restritas e a adoção destas ainda permanece como uma faculdade do juiz. Desta forma, caberá ao juiz optar, considerando o princípio do maior interesse da criança e os inúmeros danos gerados pela experiência da maternidade no cárcere, pela adoção de penas alternativas à privação da liberdade, independente da espécie de prisão - sendo esta preventiva ou não - ou do regime prisional instituído.

Entretanto, basta analisar o número de gestantes ou mães de filhos recém-nascidos, ou ainda em desenvolvimento, encarceradas para notar que a previsão normativa é pouco aplicada, vez que esta concede ao juiz o dever de considerar isoladamente cada caso e optar pela sua aplicação ou não. Neste sentido, discorre Sônia Drigo ${ }^{75}$ : "Vá à penitenciária e veja quantas gestantes de mais de sete meses estão lá; e, quando você conversa com elas, descobre que muitas têm filhos bem pequenos — ou seja, a lei não é respeitada."

A pesquisa Dar a Luz na Sombra, após realizar entrevistas com gestantes privadas de sua liberdade em diversos presídios brasileiros, conclui que o judiciário foi apontado como principal gargalo na garantia de direitos das presas. A grande maioria das mães encarceradas - 90\%- já chegam grávidas ao sistema prisional. Resta-se evidenciado então, que em contrapartida ao avanço legislativo, apesar de termos alcançado um arcabouço normativo com caráter amplamente protetor, a falta de sensibilização pelo poder judiciário para a aplicação da lei das medidas cautelares, bem como para efetivação das garantias legais no tangente ao exercício da maternidade na prisão é entristecedora.

"Foi recorrente entre as mães presas ouvidas pela pesquisa o relato de que a juíza/juiz criminal não perguntou sobre a gravidez ou sobre as filhas e filhos da ré

75 ITCC. Tecer Justiça: presas e presos provisórios na cidade de São Paulo. Instituto Terra, Trabalho e Cidadania e Pastoral Carcerária Nacional-São Paulo: ITTC, 2012. p.24 Disponível em: http://ittc.org.br/wp-content/uploads/2013/10/Sumario-Executivo-\%E2\%80\%93-Presos-e-PresasProvisorios.pdf Acesso em:10/10/2016 
- a fala de uma delas ao responder se a juíza do caso não tinha notado a sua gestação avançada, é um retrato contundente: "ela nem olhou pra mim, quanto mais pra minha barriga". Da mesma forma, nenhuma detenta com as quais conversamos tinha informações precisas de seu processo relativo à guarda e a grande maioria relatou que nunca foram intimadas e/ou levadas para audiências cíveis enquanto estavam na prisão." ${ }^{.76}$

Sobre o assunto, Daniela Canazaro de Mello conclui que:

"Haverá prejuízo de qualquer forma, seja por permanecer na prisão, pelas próprias condições do local e dinâmica prisional, seja por sair do ambiente prisional, pela separação da mãe - que tem a aptidão de ser vivenciada pela criança como uma perda. [...] É necessário, por isso, focar na redução de danos, estudar e aplicar alternativas para as mães cumprirem suas penas ou mesmo aguardar a sentença em liberdade, evitando de todas as formas o encarceramento. Devemos analisar de forma complexa e multifatorial o destino de cada criança, a fim de evitar que os danos causados deixem cicatrizes profundas. Partindo-se da premissa de que os aspectos positivos do encarceramento centram-se no potencial protetivo frente aos cuidados da saúde da mulher e de seu filho e à manutenção do vínculo materno, deve-se questionar, necessariamente, até que ponto os mesmos benefícios não seriam obtidos fora das prisões [...]" 77

Toda problemática envolvida no tema do encarceramento feminino nos leva a conclusão de que os danos causados pelo aprisionamento às mães e seus filhos são infinitamente maiores do que qualquer outro resultado trazido pelo encarceramento, que se mostra incapaz de cumprir sua finalidade ressocializadora, fazendo com que a adoção de medidas alternativas à pena privativa de liberdade se tornem a única forma de preservar seus direitos. Com isso, conclui-se que a prisão domiciliar deve ser reconhecida pelo judiciário como um direito das acusadas e condenadas enquanto mães e também de seus filhos, independentemente da prisão destas ser preventiva ou definitiva, decretada em regime aberto, semiaberto ou fechado.

\footnotetext{
${ }^{76}$ BRASIL, Ministério da Justiça. Secretaria de Assuntos Legislativos. Dar à luz na sombra: condições atuais e possibilidades futuras para o exercício da maternidade por mulheres em situação de prisão. Brasília: Ministério da Justiça, IPEA,2015.Série Pensando o Direito, n.51. p.21. Disponível em: http://www.justica.gov.br/noticias/201clugar-de-crianca-nao-e-na-prisao-nemlonge-de-sua-mae201d-diz-pesquisa/pesquisa-dar-a-luz-na-sombra-1.pdf. Acesso em: 10/11/2016. ${ }_{77}$ MELLO, Daniela Canazaro de. A prisão feminina: gravidez e maternidade: um estudo da realidade em Porto Alegre - RS/Brasil e Lisboa/Portugal - Porto Alegre, 2014. p.15 Disponível em: $<$ http://repositorio.pucrs.br/dspace/bitstream/10923/6671/1/000459044-Texto\%2bParcial\%2bv.10.Pdf> Acesso em: 02/11/2016.
} 


\subsection{Acesso precário à justiça}

Os fundamentos da criação da Defensoria Pública e, consequentemente, do acesso à justiça estão presentes Constituição Federal:

Art 5o, [...] LXXIV - o Estado prestará assistência jurídica integral e gratuita aos que comprovarem insuficiência de recursos;

Art. 134. A Defensoria Pública é instituição essencial à função jurisdicional do Estado, incumbindo-lhe a orientação jurídica e a defesa, em todos os graus, dos necessitados, na forma do art. 5o, LXXIV.

O Brasil conta com um pequeno número de defensores públicos para uma enorme população prisional. Logo, a cultura do encarceramento, a qual mantem a prisão como principal política social e de segurança pública no Brasil, acarreta no aumento descontrolado do número de presos e contribui diretamente para o aumento da precariedade no acesso à justiça prestado à estas pessoas.

Conforme constatado pela pesquisa Dar a Luz na Sombra:

"Em grande parte dos casos, a presa não tem possibilidade de se defender frente às instituições de controle: poucas têm contato, antes da audiência, com a defensora/defensor e, geralmente, não há espaços de fala - para contar sua versão dos fatos, contextualizar sua história, para além do crime eventualmente praticado. $\mathrm{O}$ alto número de prisões preventivas e sentenças condenatórias se fundamentam em provas baseadas única e exclusivamente nos depoimentos de agentes que a prenderam. É o que frequentemente ocorre em processos envolvendo tráfico de drogas, nos quais o único testemunho é de policiais que efetuaram a abordagem, dada a ausência de vítimas concretas nesse crime." ${ }^{78}$

Como resultado, a precariedade da assistência jurídica leva à falta de acesso à informação, pouca participação no processo criminal e civil, e exercício precário da defesa.

Outro resultado encontrado é a falta de informação acerca do paradeiro de seu filho. No Brasil, quando uma mãe é presa, existem três

\footnotetext{
${ }^{78}$ BRASIL, Ministério da Justiça. Secretaria de Assuntos Legislativos. Dar à luz na sombra: condições atuais e possibilidades futuras para o exercício da maternidade por mulheres em situação de prisão. Brasília: Ministério da Justiça, IPEA,2015.Série Pensando o Direito, n.51. p.75. Disponível em: http://www.justica.gov.br/noticias/201clugar-de-crianca-nao-e-na-prisaonem-longe-de-sua-mae201d-diz-pesquisa/pesquisa-dar-a-luz-na-sombra-1.pdf. Acesso em: $10 / 11 / 2016$.
} 
possibilidades para a guarda de seus filhos pequenos, dentre estas a colocação em instituição de abrigo, em família substituta - que pode ser um próprio parente da presa- ou no berçário/creche do presídio. No entanto, a fragilidade do sistema de defensoria pública faz com que muitas vezes as mulheres sequer tenham contato com os juízes responsáveis por decidirem o destina da criança.

O fenômeno ocorre também por conta da ausência de comunicação entre a Justiça Civil - onde correm os processos de guarda das crianças - e a Justiça Penal, onde são julgados os crimes pelos quais as presas são acusadas. Enquanto a Justiça Criminal ignora a situação materna vivida por estas mulheres, a Justiça Civil da Infância e Juventude sequer acompanham o processo criminal em andamento e os desconsideram nas ações de guarda de seus filhos.

Pelos motivos aqui expostos, a precariedade do acesso à justiça representa mais um dos obstáculos responsáveis por impedir a efetivação das garantias legais inerentes ao exercício da maternidade no âmbito carcerário. 


\section{Conclusão}

O estudo do aprisionamento feminino revela que este, antes de ser um problema penal, é um problema social. Estas mulheres, que na maioria das vezes são mães, acabam delinquindo por pertencerem à uma camada social mais baixa e terem suas chances de ascendência econômica e social reduzidas, encontrando no crime um caminho "de fácil acesso" para sua sobrevivência e sustento do lar. O Estado então, em uma espécie de "cegueira deliberada" que ignora os problemas sociais existentes no Brasil e insiste em prosseguir com a prática de encarceramento sistemático. Ocorre então, uma intervenção estatal impensada que, apesar da existência de um firme posicionamento internacional dos direitos humanos que repudia a imposição da pena privativa de liberdade para mulheres que vivenciam a maternidade, ignora a existência de algo maior do que sua fúria punitiva contra a criminalidade. Assim, o Estado insere estas mulheres em uma rotina guiada pela violação de seus direitos e de seus filhos, onde ocorre o fiel descumprimento das previsões legais e o brutal descaso em relação às suas especificidades.

A precariedade dos estabelecimentos, os quais possuem diversas falhas estruturais e conjunturais, fazem com que o exercício da maternidade se dê em um contexto precário. $\mathrm{O}$ acesso aos direitos mais básicos, como a saúde, integridade física e moral, amamentação, convívio familiar, educação, trabalho, acesso à justiça, dentre outros, impossibilitam que a maternidade se desenvolva de forma saudável. Os espaços específicos para exercício da maternidade são excepcionais e localizados somente em algumas capitais brasileiras, não atingindo a população prisional de forma geral. Ainda assim, mesmo os estabelecimentos considerados modelos têm falhas estruturais e conjunturais que nos permitem afirmar que o exercício da maternidade de mulheres presas nos diversos contextos brasileiros é precário. Desta forma, evidente a incapacidade reeducadora do aprisionamento, que acaba se tornando apenas um instrumento de intensificação da dor. 
Assim, conclui-se que o sistema penitenciário brasileiro não está preparado para receber estas mães e seus bebes, e mesmo que contassem com uma estrutura consideravelmente satisfatória, ainda não seria a melhor solução para o problema da maternidade no cárcere. Desta forma, o presente trabalho pugna pelo reconhecimento da incompatibilidade existente entre o instituto da maternidade e a imposição da pena restritiva de liberdade, defendendo a adoção de medidas alternativas à estas sempre que verificado tal estado biológico. Ao tratar-se de uma condenação dirigida à uma mãe, nasce o dever do julgador de considerar a realidade em que cada mulher está inserida, bem como a realidade dos presídios onde sua pena será cumprida e os efeitos devastadores que esta causará na sua vida e de seu filho. Caso este exercício reflexivo ocorra, evidente se tornará inadequação do encarceramento e a sua impossibilidade de alcance de sua função ressociabilizadora, e inevitável será a aplicação da previsão contida na LEP e a substituição pela prisão domiciliar.

Entretanto, em segundo plano, o presente estudo defende ainda a implementação de algumas mudanças e medidas imediatas, capazes de promover uma melhor adequação do ambiente prisional para o recebimento destas mães e crianças, e assim reduzir um pouco do sofrimento e obstáculos que rodeiam seu exercício. Para tanto, dentre as tantas mudanças que se fazem necessárias, surgem as propostas:

- Fim da revista vexatória

- Maior flexibilidade nos dias e horários destinados à visitação

- Criação de programas de assistência social que visem a manutenção ou resgate do vínculo afetivo entre as mulheres e seus familiares, amigos e companheiro.

- Obrigatoriedade de manutenção de equipe multidisciplinar (incluindo médicos ginecologistas, psicólogos, psiquiatras, assistentes sociais, dentre outros) 
- Promoção de melhorias na interface entre o poder judiciário e as detentas, visando possibilitar o acompanhamento de seu processo penal e de guarda da criança.

- Possibilidade de comunicação entre a detenta e o abrigo em que seu filho esteja alojado, garantindo o acompanhamento de seu desenvolvimento.

- Acesso à produtos de higiene pessoal e de características básicas para cuidados com as crianças (como fraldas, roupas, lenços, dentre outros).

- Criação ou reforma de espaços destinados à gestante e convivência materno-infantil, conforme previsto na Lei de Execução Penal. 79

- Extinção de creches no interior das penitenciárias e direcionamento das crianças à escolas da rede pública localizadas nos arredores da instituição.

- Promoção de encontros semanais, guiados por assistentes sociais e profissionais de diversos ramos da saúde, para orientação sobre o exercício da maternidade.

- Pleno acesso e estímulo à participação das mulheres em atividades laborais e educacionais no interior da instituição

Por fim, ressalta-se que as propostas aqui contidas representam apenas uma forma paliativa de reduzir algumas das diversas violações sofridas por estas mulheres no ambiente carcerário, defendendo, acima de tudo, a incompatibilidade entre o aprisionamento e o instituto da maternidade.

${ }^{79}$ BRASIL. Lei $n^{\circ} 7210$ de 11 de julho de 1984. Lei de execução Penal. Art. 89 e $83 \S 2^{\circ}$. 


\section{Bibliografia}

ARAÚJO, Aparecida do Nascimento Vieira et al. Percepção de Mães Presidiárias sobre os Motivos que Dificultam a Vivência do Binômio. Bahia. 2014. 12pg. Monografia - Núcleo de Pesquisa Saúde e Violência da Universidade do Estado da Bahia - UNEB.

BARROS, Denise Cavalcanti. O Consumo alimentar de gestantes adolescentes no Município do Rio de Janeiro. Rio de Janeiro. 2012. 9 pg. Tese de Pós Graduação. Fundação Oswaldo Cruz. Disponível em: http://teses.icict.fiocruz.br/pdf/barrosdcm.pdf Acesso em: 10/11/2016

BASTOS, Paulo Roberto da Silva. Criminalidade feminina: Estudo do perfil da população carcerária feminina da Penitenciária Professor Ariosvaldo de Campos Pires - Juiz de Fora (MG)/2009. Disponível em: http://www.ambitojuridico.com.br/site/index.php?n_link=revista_artigos_leitura\&artigo_id=8 444 Acesso em: 05/11/2016

BISPO, Tânia Cristiane Ferreira et al. Gestar e parir na prisão: difíceis caminhos. VII Jornadas Santiago Wallace de Investigación em Antropologia Social. Sección de Antropologia Social. Instituto de Ciencias Antropologicas. Facultad de Filosofia y Letras, UBA, Buenos Aires, 2013. 20pag. Disponível em: http://www.aacademica.com/000-063/187.pdf Acesso em: 10/11/2016

BOITEUX, Luciana, FERNANDES, Maíra, PANCIERI, Aline e CHERNICHARO, Luciana. Mulheres e crianças encarceradas: um estudo jurídico-social sobre a experiência da maternidade no sistema prisional do Rio de Janeiro. 5 pag. Disponível em: http://pbpd.org.br/wordpress/wpcontent/uploads/2015/11/M--es-encarceradas-UFRJ.pdf Acesso em $15 / 10 / 2016$ 


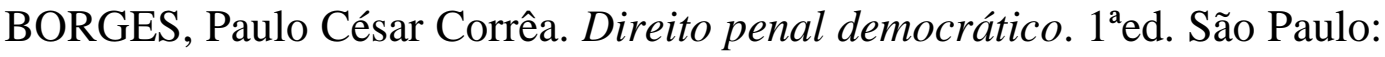
Lemos e Cruz, 2005. 360pag.

BRAGA, Ana Gabriela Mendes; ANGIOTTI, Bruna. Da Hipermaternidade à Hipomaternidade no Cárcere Feminino Brasileiro.2015. Revista Internacional de Direitos Humanos. SUR 22 - v.12 n.22. 11pag. Disponível em: $\quad$ http://sur.conectas.org/wp-content/uploads/2015/12/16_SUR22_PORTUGUES_ANA-GABRIELA-MENDES-BRAGA_BRUNAANGOTTI.pdf Acesso em: 20/10/2016

BRASIL, Ministério da Justiça, Departamento Penitenciário Nacional, Levantamento nacional de informações penitenciárias - INFOPEN dezembro 2014 (Brasília: Ministério da Justiça, Depen, 2014). 80pag. Disponível em: https://www.justica.gov.br/seus-direitos/politicapenal/infopen_dez14.pdf Acesso em: 10/10/2016

BRASIL, Ministério da Justiça, Departamento Penitenciário Nacional, Levantamento nacional de informações penitenciárias - INFOPEN Mulheres - junho 2014 (Brasília: Ministério da Justiça, Depen, 2014). 42pag. Disponível em: https://www.justica.gov.br/noticias/estudo-traca-perfil-dapopulacao-penitenciaria-feminina-no-brasil/relatorio-infopen-mulheres.pdf Acesso em: 10/10/2016

BRASIL, Ministério da Justiça. Secretaria de Assuntos Legislativos. Dar à luz na sombra: condições atuais e possibilidades futuras para o exercício da maternidade por mulheres em situação de prisão. Brasília: Ministério da Justiça, IPEA,2015.Série Pensando o Direito, n.51. 92pag. Disponível em: http://www.justica.gov.br/noticias/201clugar-de-crianca-nao-e-na-prisaonem-longe-de-sua-mae201d-diz-pesquisa/pesquisa-dar-a-luz-na-sombra1.pdf. Acesso em: 10/11/2016.

BRASIL. Núcleo Especializado da Infância e Juventude - Defensoria Pública de São Paulo. Mães no cárcere: Observações técnicas para a atuação profissional em espaços de convivência de mulheres e seus filhos. São Paulo, 2011. 10pag. Disponível em: 
http://www.saude.sp.gov.br/resources/ses/perfil/profissional-dasaude/grupo-tecnico-de-acoes-estrategicas-gtae/saude-das-populacoesprivadas-de-liberdade/saude-do-sistema-penitenciario/cartilha-maes-nocarcere/cartilha_maes_no_carcere.pdf Acesso em: 10/10/2016

BRASIL. Constituição da República Federativa do Brasil de 1988.

BRASIL. Decreto-Lei 2.848, de 07 de dezembro de 1940. Código Penal. Diário Oficial da União, Rio de Janeiro, 31 dez. 1940.

BRASIL. Lei de execução Penal. Lei no 7210 de 11 de julho de 1984.

BRASIL. Lei federal $\mathrm{n}^{\circ}$ 8069, de 13 de julho de 1990. Estatuto da criança e do adolescente. Art. 8 \$7.

BRASIL. Ministério da Justiça. Secretaria Especial de Política para as Mulheres. Reorganização e reformulação do sistema prisional feminino: Relatório final. 2007. 90pag. Disponível em: <http://portal.mj.gov.br/depen/main.asp?ViewID=\%7B71FD341F-05314BAB-A567-72586745CB18\%7D \& params $=$ itemID $=\% 7 \mathrm{~B} 0892 \mathrm{E} 0 \mathrm{~A} 1-$ 29D4-4E56-AF95-6B4B6EC869A2\%7D;\&UIPartUID=\%7B2868BA3C1C72-4347-BE11-A26F70F4CB26\%7D Acesso em: 07/11/2016

BRASIL. Ministérios da Saúde e da Justiça. Portaria Interministerial n.1777/GM, de 09 de setembro de 2003. Aprova o Plano Nacional de Saúde no Sistema Penitenciário e define financiamento. Brasília: Ministério da Saúde; 2003

BUSS, Paulo Marchior; FILHO, Alberto Pellegrini. A Saúde e seus Determinantes Sociais - Revista Saúde Coletiva Physis. 2007. 17pag. Disponível em: http://www.scielo.br/pdf/physis/v17n1/v17n1a06.pdf. Acesso em: 12/11/2016

CARVALHO, Denise; JESUS, Maria Gorete Marques de. Mulheres $e$ oTráfico de Drogas: Um Retrato das Ocorrências de Flagrante na Cidade de São Paulo. Revista do Laboratório de Estudos da Violência da UNESP/Marília. 2012. Ed. 9 - Maio/2012. 16pag. Disponível em: 
http://www2.marilia.unesp.br/revistas/index.php/levs/article/view/2285/188

2 Acesso em: 05/10/2016

CARVALHO, Maria Lazaro et al. Perfil dos internos no sistema prisional do Rio de Janeiro: especificidades de gênero no processo de exclusão social. In: Ciência e Saúde Coletiva. 2006 Abr-Jun; 11(2). 11pag. Disponível em: http://www.scielo.br/pdf/csc/v11n2/30433.pdf Acesso em: 10/11/2016

CARVALHO, Salo. O papel dos atores do sistema penal na era do punitivismo. Rio de Janeiro: Lumen Juris, 2010. 290pag.

CEJIL, Centro pela Justiça e pela Justiça Internacional et al. Relatório sobre as mulheres encarceradas no Brasil. Rio de Janeiro,2007. 61pag. Disponível em: http://carceraria.org.br/wpcontent/uploads/2013/02/Relato\%CC\%81rio-para-OEA-sobre-MulheresEncarceradas-no-Brasil-2007.pdf Acesso em: 05/11/2016.

CERNEKA, Heidi Ann. Homens que menstruam: Considerações acerca do sistema prisional às especificidades da mulher. 2009. 18pag. Disponível em: http://www.domhelder.edu.br/revista/index.php/veredas/article/view/6.

Acesso em: 25/10/2016

CNJ. Lei sobre drogas deve mudar para evitar penas desproporcionais à mulher, defende juíza. 2013. Disponível em: http://www.cnj.jus.br/noticias/cnj/60511-lei-sobre-drogas-deve-mudar-paraevitar-penas-desproporcionais-a-mulher-defende-juiza Acesso em: 20/10/2016.

CNJ. População carcerária feminina $567 \%$ em 15 anos no Brasil. 2015 Disponível em: http://cnj.jus.br/noticias/cnj/80853-populacao-carcerariafeminina-aumentou-567-em-15-anos-no-brasil. Acesso em: 08/11/2016

COLMEIA, Z. Família e Cárcere: os efeitos da punição sobre a unidade familiar e a necessidade de inclusão. Boletim do Centro de Apoio Operacional das Promotorias Criminais, do Júri e de Execuções Penais Área de Execução Penal no 86 -maio/2011.p.13 
CONECTAS. Mulheres e Encarceradas: Dupla Punição. Disponível em: http://www.conectas.org/pt/acoes/justica/noticia/28793-mulheres-eencarceradas-dupla-punicao. Acesso em: 16/10/2016

ESPINOZA, Olga. A mulher encarcerada e face do poder punitivo. São Paulo: IBCCrim, 2004.

IBGE, Brasil População total, homens e mulheres 2000-2030. Disponível em:http://seriesestatisticas.ibge.gov.br/series.aspx ?no=10\&op=0\&vcodigo $=$ POP119\&t=taxa-media-geometrica-crescimento-anual-populacao Acesso em: 10/09/2016

INFOPEN. Sistema carcerário nacional tem apenas 15 ginecologistas para 35 mil mulheres presas. Veiculado pelo Ministério da Justiça, dezembro de 2012. Disponível em: http://www.cnj.jus.br/noticias/cnj/25949:sistemacarcerario-nacional-tem-apenas-15-ginecologistas-para-35-mil-mulherespresas. Acesso em: 10/11/2016

ITCC. Tecer Justiça: presas e presos provisórios na cidade de São Paulo. Instituto Terra, Trabalho e Cidadania e Pastoral Carcerária Nacional- São Paulo: ITTC, 2012. 26pag. Disponível em: http://ittc.org.br/wpcontent/uploads/2013/10/Sumario-Executivo-\%E2\%80\%93-Presos-ePresas-Provisorios.pdf Acesso em:10/10/2016 JESUS, Amanda Costa Freitas et al. O significado e a vivência do abandono familiar para presidiárias. In: Ciência e Saúde. Jan.-abr.2015;(8):19-25. 7 pag. Disponível em: http://revistaseletronicas.pucrs.br/ojs/index.php/faenfi/article/view/19535. Acesso em: 08/10/2016

KUROWSKI, Cristina Maria. Análise crítica quanto a aspectos de implantação e funcionamento de uma creche em penitenciária feminina. Porto Alegre, 1990. 37f.

LIMA, Marcia. Da visita íntima à intimidade da visita: a mulher no sistema prisional. Tese de Mestrado. Universidade de São Paulo. São Paulo, 2006. 
106pag.

Disponível

em:

http://www.teses.usp.br/teses/disponíveis/6/6136/tde-24032008-085201/ptbr.php Acesso em: 11 nov. 2016

LOBATO, Aline et al. Mulheres criminosas: analisando a relação entre a desestruturação familiar e criminalidade. 10pag. Disponível em: http://abrapso.org.br/siteprincipal/images/Anais_XVENABRAPSO/242.\%2 0mulheres\%20criminosas.pdf Acesso em: 20/10/2016

LOPES, Aury Jr. Direito processual penal e sua conformidade

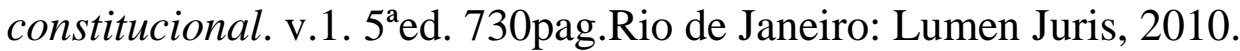

MELLO, Daniela Canazaro de. A prisão feminina: gravidez e maternidade: um estudo da realidade em Porto Alegre - RS/Brasil e Lisboa/Portugal Porto Alegre, 2014. Disponível em: <http://repositorio.pucrs.br/dspace/bitstream/10923/6671/1/000459044Texto\%2bParcial\%2bv.1-0.Pdf> Acesso em: 02/11/2016.

MINZON, Camila Valéria; DANNER, Glaucia Karina; BARRETO, Danielle Jardim. Sistema prisional: conhecendo as vivências da mulher inserida neste contexto. Akrópolis Umuarama, v.18, n.1, 2010. Disponível em: http://revistas.unipar.br/akropolis/article/viewFile/3118/2212. Acesso em: $05 / 11 / 2016$

NOVAES, Elizabete David. Uma Reflexão Teórico-Sociológica acerca da inserção da Mulher na Criminalidade. Revista Sociologia Jurídica. $\mathrm{n}^{\circ} 10$. Jan/jun 2010. Disponível em: http://www.sociologiajuridica.net.br/ Acesso em: 20/10/2016.

NUCCI, Guilherme de Souza. Manual de processo penal e execução penal: 4 ed. - São Paulo: Editora Revista dos Tribunais,2008.

NUCCI, Guilherme de Souza. Prisão e Liberdade. As reformas processuais penais introduzidas pela Lei 12.403, de 4 de maio de 2011. São Paulo: Revista dos Tribunais. $2^{\circ}$ tiragem. p.76 
OMS, Organização Mundial da Saúde. Constituição da Organização Mundial da Saúde (OMS/WHO) - 1946. USP. p.1 Disponível em: http://www.direitoshumanos.usp.br/index.php/OMS-Organização-Mundialda-Saúde/constituicao-da-organizacao-mundial-da-saude-omswho.html Acesso em: 10/11/2016.

ONU. Regras de Bangkok. Adotada pela Assembleia Geral em 16/03/11. Resolução A/RES/65/229. 80pag. Disponível em: http://www.cnj.jus.br/files/conteudo/arquivo/2016/03/27fa43cd9998bf5b43 aa2cb3e0f53c44.pdf Acesso em: 03/10/ 2016

PEREIRA, Larissa Urruth, ÁVILA, Gustavo Noronha. Política de Drogas e Aprisionamento Feminino - O Tráfico e o uso na Lei de Drogas. 2013. 15 pag. Disponível em: http://ebooks.pucrs.br/edipucrs/anais/cienciascriminais/IV/46.pdf Acesso em: 10 nov. 2016

PEREIRA, Larissa Urruth. Do berço à cela - A Extensão das Penas na Penitenciária Feminina Madre Pelletier. 29 pag. Disponível em: http://www.publicadireito.com.br/artigos/?cod=eca336bc46296c1a Acesso em: 10/11/2016

QUEIROZ, Nana. Disponível em: http://folhanobre.com.br/2016/03/08/descubra-como-e-vida-das-mulheresnas-penitenciarias-brasileiras/23761. Acesso em: 11/11/2016.

RIBEIRO, Ludmila Mendonça Lopes. Análise da política penitenciária feminina do Estado de Minas Gerais: o caso da Penitenciária Industrial Estevão Pinto. 2003. Dissertação de Mestrado. Belo Horizonte: Fundação João Pinheiro, 2003, 164f. Disponível em: http://bdtd.ibict.br/vufind/Record/FJP_5ef6b8e30765344b1c00c4c471fd867 6. Acesso em: 10/10/2016

SANTOS, José Heitor. Aleitamento materno nos presídios femininos. Disponível em: 
http://www.mp.rs.gov.br/infancia/doutrina/id103.htm;http://www.mp.rs.gov .br/infancia/doutrina/id103.htm>. Acesso em 30/10/2016

SANTOS, Marcos Davi dos et al. Formação em pré-natal, puerpério e amamentação: praticas ampliadas. São Paulo: Fundação Maria Cecilia Souto Vidigal, 2014. (Coleção primeiríssima infância; v. 3). 140pag.

SEIXAS, Taysa Matos. Os filhos da outra: A mulher e a gravidez no cárcere. 2016. Disponível em: http://emporiododireito.com.br/tag/amamentacao/ Acesso em: 25/10/2016

SIMONE, Vanessa Fusco Nogueira. Filhos do cárcere: limites e possibilidades de garantir os direitos fundamentais dos filhos das mulheres privadas de liberdade no Brasil. Porto Alegre: Núria Fabris, 2013. 168pag.

SOUZA, Jorge Gauthier Santos. Mães, filhos e cárcere: O nascimento atrás das grades. Salvador. 2009. 8pag. Monografia - Universidade Federal da Bahia.

STELLA, Cláudia. Filhos de mulheres presas: soluções e impasses para seus desenvolvimentos. São Paulo: LCTE Editora, 2006. 123pag. 